\title{
Hungary: First Review Under the Stand-By Arrangement and Request for Modification of Performance Criteria-Staff Report; Staff Statement; and Press Release on the Executive Board Discussion
}

In the context of the first review under the Stand-By Arrangement and request for modification of performance criteria, the following documents have been released and are included in this package:

- $\quad$ The staff report for First Review Under the Stand-By Arrangement and Request for Modification of Performance Criteria, prepared by a staff team of the IMF, following discussions that ended on February 16, 2009, with the officials of Hungary on economic developments and policies. Based on information available at the time of these discussions, the staff report was completed on March 12, 2009. The views expressed in the staff report are those of the staff team and do not necessarily reflect the views of the Executive Board of the IMF.

- A staff statement of March 25, 2009, updating information on recent developments.

- $\quad$ A Press Release summarizing the views of the Executive Board as expressed during its March 25, 2009 discussion of the staff report that completed the review.

The documents listed below have been or will be separately released.

Letter of Intent sent to the IMF by the authorities of Hungary*

Technical Memorandum of Understanding*

*Also included in Staff Report

The policy of publication of staff reports and other documents allows for the deletion of market-sensitive information.

Copies of this report are available to the public from

International Monetary Fund • Publication Services

$70019^{\text {th }}$ Street, N.W. • Washington, D.C. 20431

Telephone: (202) 623-7430 • Telefax: (202) 623-7201

E-mail: publications@imf.org•Internet: http://www.imf.org

\section{International Monetary Fund Washington, D.C.}



INTERNATIONAL MONETARY FUND

HUNGARY

\title{
First Review Under the Stand-By Arrangement and Request for Modification of Performance Criteria
}

\author{
Prepared by the European Department \\ (In Consultation with Other Departments)
}

Approved by Anne-Marie Gulde and Lorenzo Giorgianni

March 12, 2009

- Stand-By Arrangement: a 17-month SBA in the amount of SDR 10.5 billion ( $€ 12.3$ billion, $\$ 15.7$ billion, 1015 percent of quota) was approved by the Executive Board (Country Report No. 08/361) on November 6, 2008, and a first purchase of SDR 4.2 billion was made following the Board meeting. As required under the Emergency Financing Mechanism, the staff report for interim review (Country Report No. 09/21) was issued on December 23, 2008. The second tranche, subject to the completion of this (first) review, amounts to SDR 2.1 billion. The European Commission and the World Bank are also providing funds to cover the financing gap under the program.

- Program status: All end-December 2008 quantitative performance criteria and the continuous performance criterion on non-accumulation of external arrears were met, as well as the end-December indicative target on central government debt. End-December inflation breached the lower inner band, and a discussion was held with staff. The structural performance criterion on submission to parliament of a draft support package for domestic banks by November 10, 2008, was observed, as were the endDecember 2008 structural benchmarks of passage of the fiscal responsibility law and submission to parliament of amendments granting the Hungarian Financial Supervision Agency (HFSA) special remedial powers.

- Discussions. Discussions were held in Budapest during February 4-16. The mission met with Prime Minister Gyurcsány, Minister of Finance Veres, Minister of the Economy and Development Bajnai, central bank Governor Simor and other senior officials, parliamentarians, representatives of financial institutions, and academics. The staff team comprised Messrs. Morsink (head), Wiegand, Joshi, and Ms. Ivaschenko (all EUR), Mses. Barkbu (SPR) and Luedersen (LEG), and Messrs. Debrun (FAD), Frécaut and Giustiniani (both MCM).

- Publication. The Hungarian authorities intend to allow the publication of the staff report. 


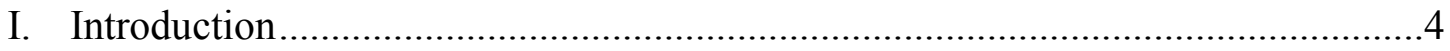

II. Recent Developments .......................................................................................

III. Policy Discussions ..................................................................................... 7

A. Macroeconomic Framework …............................................................ 7

B. Fiscal Policy ....................................................................................... 10

C. Financial Sector Policies......................................................................... 12

D. Monetary and Exchange Rate Policy ....................................................... 14

IV. Program Modalities and Safeguards Assessment .............................................. 15

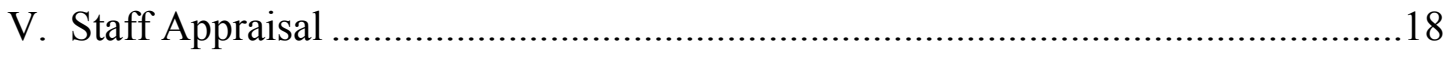

Boxes

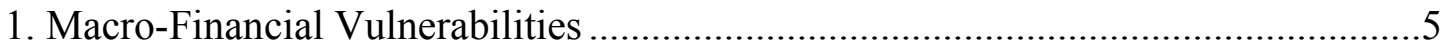

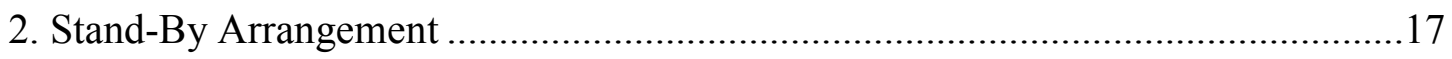

Tables

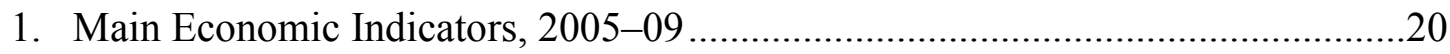

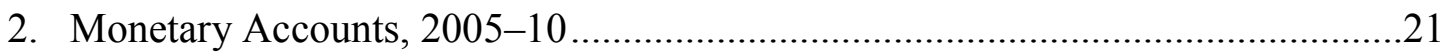

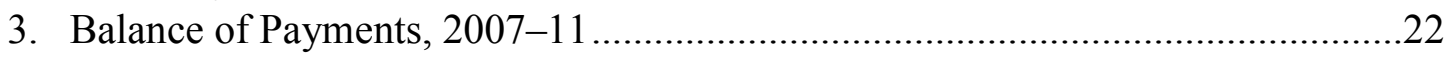

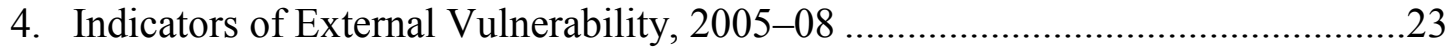

5. Staff's Illustrative Medium-Term Scenario, 2005-11 .......................................24

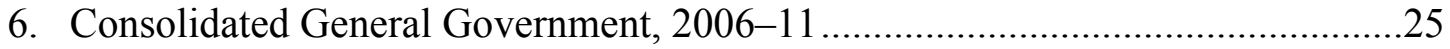

7. Borrowing Requirements of the Central Government, 2008-10 ........................26

8. Financial Soundness Indicators for the Banking Sector, 2000-08 ......................27

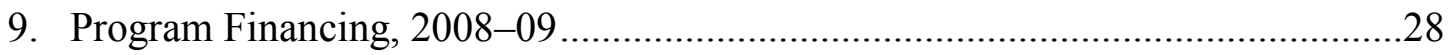

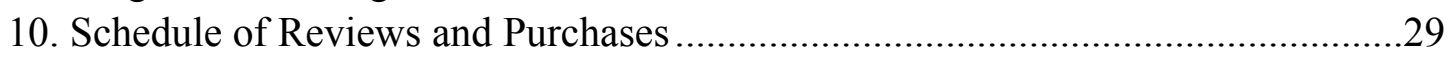

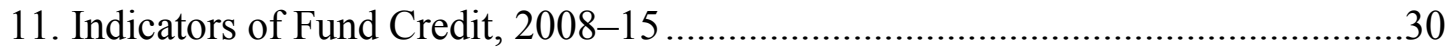

Figures

1. Financial Market Developments, 2008-09 ........................................................6

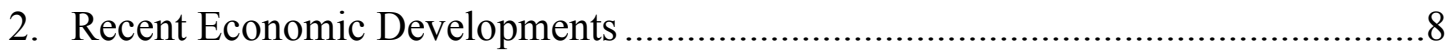

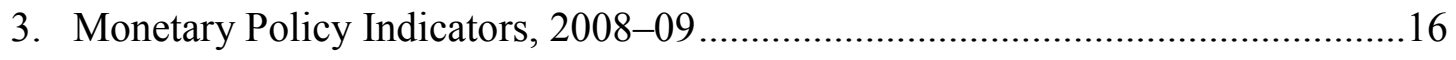

Appendix Tables

1. Public Sector Debt Sustainability Framework, 2004-14 ........................................ 31

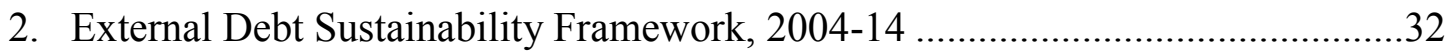


Appendix Figures

1. Public Debt Sustainability: Bound Tests

2. External Debt Sustainability: Bound Tests

Attachment

1. Letter of Intent .35

Technical Memorandum of Understanding ................................................4 


\section{INTRODUCTION AND SUMMARY}

1. Policy implementation has been in line with the program, but the economic outlook has worsened and financial market stress persists. The performance criteria, indicative target, structural performance criterion and benchmarks for 2008Q4 were all met. However, economic growth in partner countries and global financial market conditions are turning out to be worse than anticipated. The combination of the deterioration of the global environment and Hungary's high balance sheet vulnerabilities is undermining the economic outlook (Box 1).

2. The policy settings under the program have been revised in light of the deterioration in the macroeconomic outlook:

- $\quad$ The additional fiscal measures aim to strengthen fiscal sustainability while avoiding an excessively large negative impulse to demand, by combining permanent reductions in spending with a temporary slowing of headline fiscal consolidation.

- $\quad$ The revised program puts additional emphasis on measures to help preserve financial stability, including ensuring the continuity of the safety net for banks, strengthening the remedial action and resolution regimes, and improving the HFSA's capabilities.

- $\quad$ Monetary and exchange rate policy will continue to target inflation over the medium term while being prepared to act as needed to mitigate risks to financial stability.

3. The authorities have strong ownership of their program, but implementation risks remain. The most significant risks are a further deterioration in the outlook for trading partners, a further delay in the expected improvement in the global financial environment, and a sharper-than-projected contraction in domestic demand. The authorities are committed to make policy adjustments that may become necessary. However, the political situation in Hungary is fragile, with the ruling party short of a majority in parliament. To help foster broad-based ownership of the program, Fund staff have undertaken extensive outreach to the media and the political opposition.

\section{Fund staff have continued to cooperate closely with the staff of the European}

Commission (EC). Since the announcement of the program, Fund and EC staff have consulted each other regularly regarding economic and policy developments in Hungary. The first tranche ( $€ 2$ billion) of the EU's balance of payment support was disbursed in December 2008. In connection with the second disbursement (€2 billion), which is expected in March, the EC fielded a parallel mission, which attended the same meetings with the authorities as the Fund mission. Fund staff have also cooperated closely with World Bank staff. 


\section{Box 1. Hungary: Macro-Financial Vulnerabilities}

Financial market strains result from the confluence of global deleveraging and high underlying balance sheet vulnerabilities.

- $\quad$ Public debt is high. Fiscal deficits were large for much of the early 2000s, averaging more than 8 percent of GDP between 2002 and 2006. General government debt is estimated to be 72 percent of GDP at end-2008. As a consequence, the government's refinancing needs are substantial.

- Private sector debt also grew rapidly, fueled by capital inflows that were spurred by easy financing conditions in the context of Hungary's EU accession. Gross external debt is estimated at 114 percent of GDP for end-2008.

- Bank lending in foreign currencies is widespread. As a result, Hungarian households and corporations have accumulated sizeable and largely unhedged foreign currency debts. This renders the private sector vulnerable to a depreciation of the Hungarian forint, which, in turn, would translate into deteriorating credit quality for the banking sector.

\section{RECENT DEVELOPMENTS}

5. After moderating in November and December, financial market strains have intensified again recently (Figure 1):

- $\quad$ The forint appreciated slightly following the announcement of the program, but has depreciated considerably since the turn of the year. The recent depreciation reflects global deleveraging and the weaker-than-expected macroeconomic outlook, and has been roughly in line with exchange rate movements of some other Central European currencies.

- $\quad$ The government securities market has been mixed. Auctions of short-term government bills have generally gone well, but in recent weeks the bid-to-cover ratio has fallen and the bid spread has risen. The government was able to auction long-term bonds in February for the first time since October, but plans for further auctions have been canceled. In the secondary market, yields have increased across the board since the start of 2009. The CDS spread has risen back to the levels observed in October.

- Banks' operating environment is deteriorating. Since October, banks have focused on accumulating liquid assets to better withstand liquidity shocks, while lending to the economy has come to a standstill. For many banks, especially those lacking a strong foreign parent, foreign currency funding is expensive and available at short maturities only. Profits fell sharply in the fourth quarter of 2008, owing to higher funding costs and provisions, and loan delinquencies have begun to rise. 
Figure 1. Hungary: Financial Market Developments, 2008-09
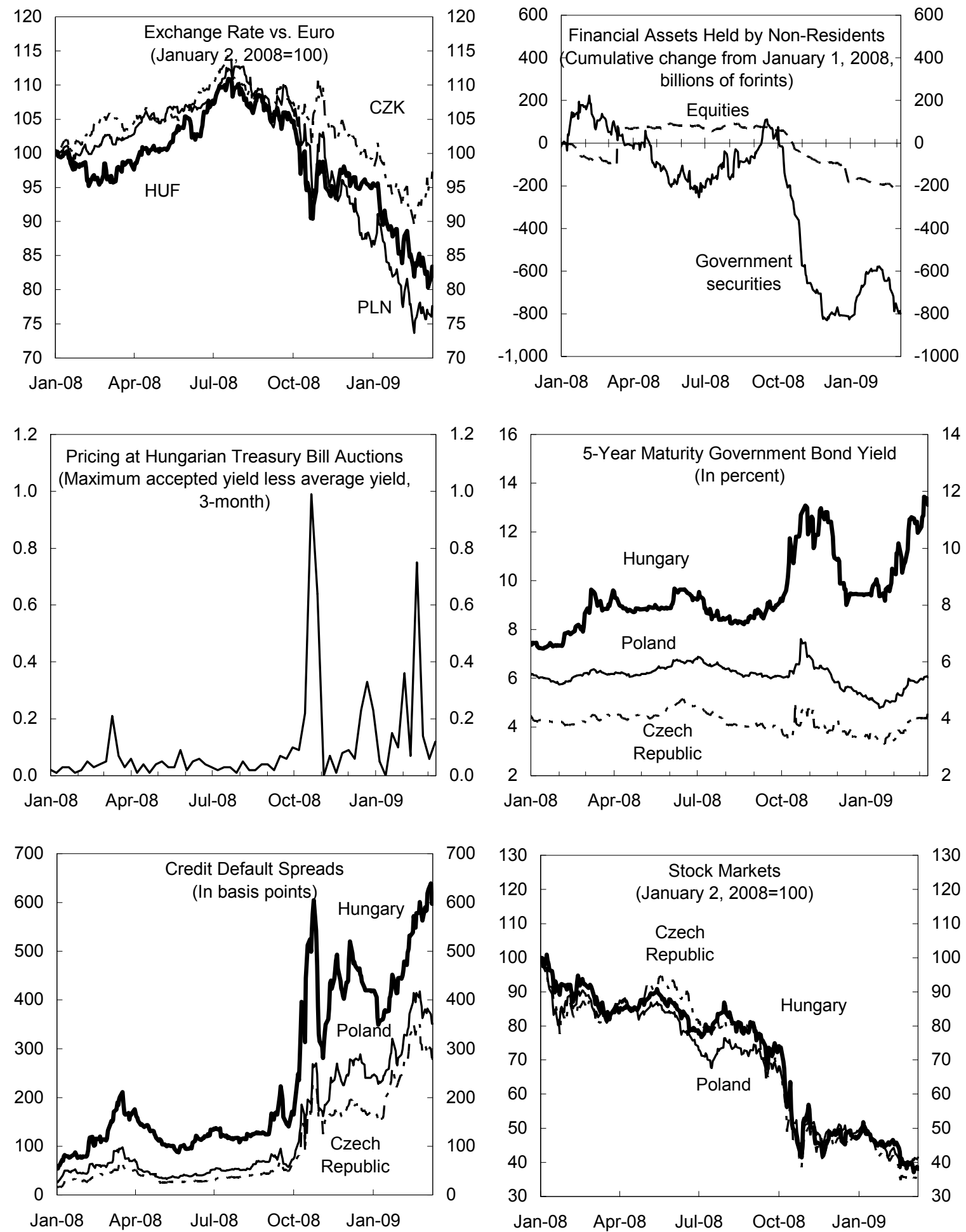

Sources: National authorities; Bloomberg; and AKK. 
- $\quad$ External financing was stronger than expected in 2008Q4, but has come under pressure again recently. Parent bank funding of their Hungarian subsidiaries increased in 2008Q4, but has since remained stable. Nonresidents' holdings of forintdenominated government securities fell sharply through December. Hungary's external debt is estimated to have increased to 114 percent of GDP at end-2008, reflecting the higher-than-expected external financing.

6. The economic downturn is turning out to be sharper than originally envisaged, mostly reflecting the deterioration of the external environment (Table 1 and Figure 2).

- Growth is slowing sharply. Real GDP data for the second half of 2008 came in much weaker than expected, resulting in a (preliminary) growth rate of 0.6 percent for 2008 as a whole (compared to 1.8 percent under the original program). Industrial output fell by 23 percent in January (y-o-y), owing to large declines in the car and consumer electronics industries. The Purchasing Managers Index and the economic sentiment index both fell to all-time lows in January. The unemployment rate increased to 8.4 percent in the three months to January. Anecdotal evidence points to an increase in the pace of layoffs, especially in sectors that are sensitive to external demand. Real estate prices have been flat, amid low turnover.

- $\quad$ CPI inflation is falling quickly. Inflation declined from 6.7 percent in June 2008 to 3.0 percent in February 2009. Private sector wage growth excluding bonuses slowed to 6.8 percent $\mathrm{y}-\mathrm{o}-\mathrm{y}$ in December.

- $\quad$ The current account deficit has remained large. The current account deficit in 2008Q4 is expected to be about 8 percent of GDP, 2 percentage points of GDP higher than under the original program. While imports have contracted sharply, so have exports, reflecting the collapse of external demand.

\section{Policy discussions}

\section{A. Macroeconomic Framework}

7. The revised macroeconomic framework for 2009 reflects the impact of the worse external environment on Hungary's outlook (LOI $95-8$ ).

- $\quad$ Real GDP growth is now projected at -3.3 percent, compared to -1.0 percent under the original program. Weaker exports reflect the worse economic outlook for the euro area and the rest of the world. Weaker investment (and imports) reflect the impact of tighter-than-expected global financial conditions on credit conditions in Hungary. This forecast is subject to large uncertainties, including growth in partner countries, 
Figure 2. Hungary. Recent Economic Developments
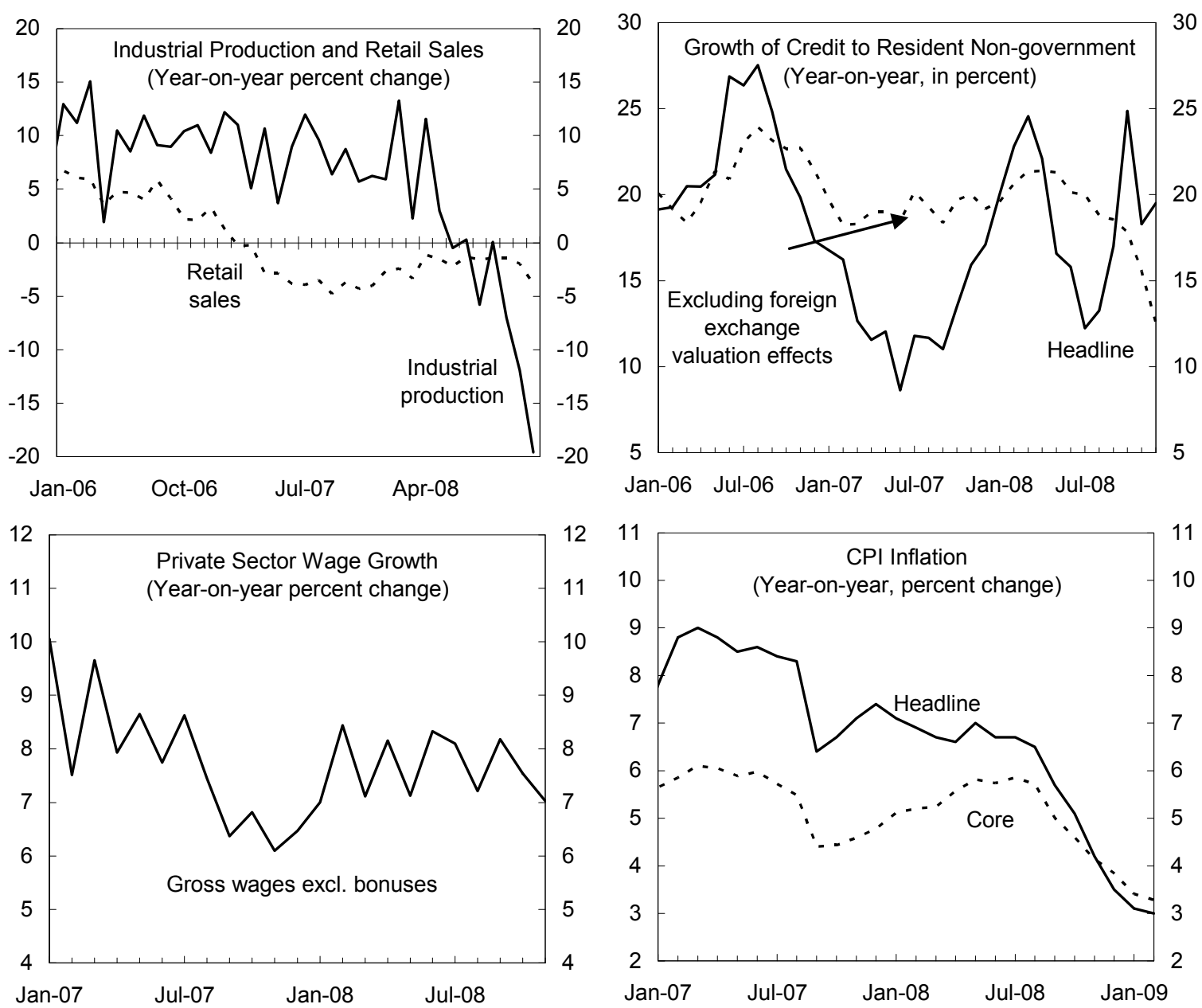

Jan-06 Jul-06 Jan-07 Jul-07 Jan-08 Jul-08
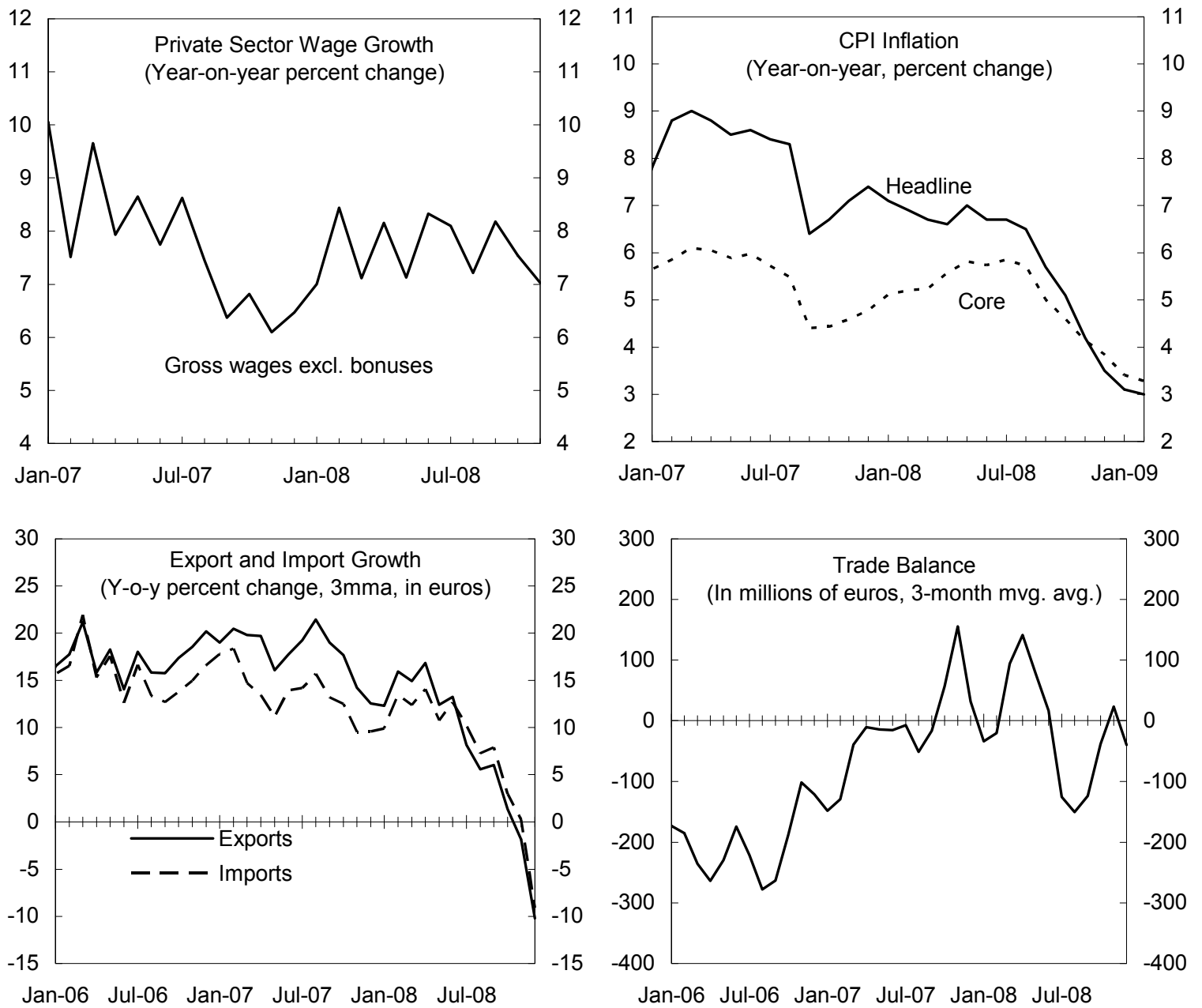

Sources: Hungarian Statistical Office; and IMF staff calculations. 
global investor appetite for Hungarian assets (especially in light of increased debt issuance by advanced economies), the severity of the credit crunch in Hungary, and the speed with which EU-funded projects can be implemented.

- CPI Inflation is also projected to be lower than under the original program. A larger output gap and lower global energy prices are expected to dampen price pressures, which will more than offset higher value-added and excise taxes. Average inflation in 2009 is now projected to be 3.8 percent, compared to 4.5 percent under the original program.

- Bank credit to the economy (excluding valuation changes) is expected to contract in nominal terms (Table 2), reflecting weak demand, efforts by banks to preserve capital, and funding constraints. Deposit growth is projected to stagnate as corporations are drawing down deposits to cover financing needs, even though household deposits may increase due to higher precautionary savings.

- $\quad$ The current account deficit is expected to narrow to 3.9 percent of GDP (Table 3). The size of the adjustment relative to 2008 - roughly 4 percent of GDP - is in line with the original program projections. Projections for both imports and exports have been revised down.

- $\quad$ The fragility of global financial markets warrants continued cautious external financing assumptions. External financing held up better than projected in 2008Q4, leading to an increase in net international reserves considerably above the program floor. However, given the shortening maturity of external debt, gross reserves still do not cover short-term debt at remaining maturity (Table 4). With the risks going forward being substantial, the authorities and staff agreed to maintain the cautious rollover assumptions contained in the original program. In particular, parent banks are assumed to roll over 80 percent of funding to their subsidiaries, and rollover rates for other forms of debt, including corporate debt, are assumed to be 70 percent.

- Given the high degree of uncertainty surrounding private external financing, official external financing provides resources for the authorities to mitigate downward pressure on the exchange rate. Available instruments include foreign exchange swaps, the bank support package, and intervention in the event of disorderly market conditions. In the program projections, the use of such resources would exceed disbursements from the EU and the World Bank, resulting in a gradual decline in the central bank's net foreign assets (NFA). ${ }^{1}$ The central bank would sterilize the fall in NFA by injecting forint liquidity. Government deposits at the central bank

\footnotetext{
${ }^{1}$ IMF disbursements to the central bank are neutral for the central bank's NFA, as they create both a foreign asset and a foreign liability. EU and World Bank disbursements increase the central bank's NFA and decrease net domestic assets (NDA), as the government's deposits with the central bank increase.
} 
would remain roughly stable, as disbursements from the EU and World Bank would be used to finance the fiscal deficit and help meet the government's external debt obligations.

\section{Over the medium term, economic growth is anticipated to recover only slowly} (Table 5). The real deprecation of the exchange rate, combined with the projected rebound in growth in partner countries, should stimulate demand for exports. The eventual moderation of global financial market stress is expected to support private investment, especially as fiscal measures under the program buttress fiscal sustainability.

\section{The program aims to put government and external debt on sustainable paths} (Appendix Tables 1 and 2, and Appendix Figures 1 and 2). A steady rise in the primary surplus is essential to keep the government debt-to-GDP ratio firmly on a declining path under a broad range of adverse shocks. The external debt-to-GDP ratio is expected to peak at 131 percent at end-2009, higher than under the original program because of a weaker exchange rate and lower nominal GDP, and then gradually decline. The debt outlook would worsen significantly if the exchange rate was to depreciate further

\section{B. Fiscal Policy}

10. Fiscal performance in $\mathbf{2 0 0 8}$ was in line with the program, owing mainly to good expenditure control (Table 6 and Text Figure). The primary surplus of the central government system was 0.8 percent of GDP, slightly above the program floor (performance criterion). The freeze of most budgetary reserves kept expenditure in check, while revenue performance was good despite shortfalls in corporate income tax and higher tax arrears (mainly owing to bankruptcies). The overall deficit of the central government system for 2008 is estimated at 3.3 percent of GDP (both on an accrual and cash basis), or 0.1 percentage point better than under the original program. The budget for 2009 (adopted by parliament in December 2008) was consistent with the size of the fiscal adjustment envisaged under the program, though the decline in the wage bill was smaller than expected (mainly offset by smaller reserves) (see Country Report No. 09/21, ๆ8).

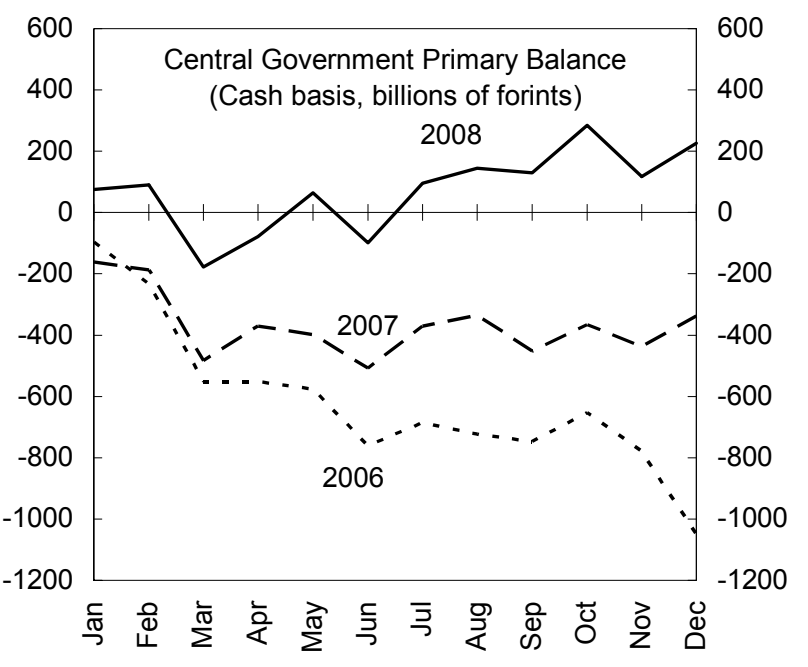

Source: Hungarian authorities and staff calculations.

11. Looking forward, the revised program aims to preserve a credible commitment to fiscal sustainability while mitigating the adverse effect on growth. The key immediate 
issue is how to address the revenue shortfall associated with the weaker macroeconomic outlook (estimated to be about 1.1 percent of GDP relative to the 2009 budget). Given still fragile external financing conditions, a reduction in the government's financing need between 2008 and 2009 is essential to build confidence in fiscal sustainability. However, with substantial fiscal adjustment already under way in 2009, it is also important to limit the negative impact on demand in the short term. The authorities and staff agree that a temporary slowing of headline fiscal consolidation should not be detrimental to market confidence if accompanied by measures that give assurance about future adjustment.

\section{To enhance fiscal sustainability, the revised program includes comprehensive structural measures that yield a permanent reduction in spending over the medium} term (LOI 915$)$. In line with past staff advice and with the need to protect the poor, the core measures are pension reform (performance criterion), improving the targeting of social transfers, and rationalizing subsidies. However, in staff's view, the new indexation formula for pensions is complicated and procyclical, and entails lower long-term savings than straight price indexation. In addition, further reforms of social transfers (such as maternity leave and housing subsidies) would still be desirable. Nevertheless, the budgetary saving from the measures in the program should grow over time, reaching 1.2 percent of GDP in 2010 and 1.4 percent of GDP in 2011.

13. To mitigate the adverse impact on growth, the revised program relaxes the fiscal deficit target for 2009 from 2.6 percent of GDP to 2.9 percent of GDP (LOI 912 ). Given the downward revision to economic activity, this implies an increase in the targeted structural adjustment from 2.5 percentage points of GDP to 3.3 percentage points of GDP. Although staff recommended a slightly higher deficit target to limit the procyclicality of fiscal policy, the authorities preferred a general government deficit target (accrual basis) of below 3 percent of GDP in line with EU commitments. Regarding the composition of the additional adjustment, staff suggested a mix of well-targeted tax and expenditure measures to limit the impact on demand, but the authorities preferred spending cuts, given the high level of government expenditure. The measures in the revised program are expected to yield savings of about $3 / 4$ percent of GDP, with the largest contributions coming from cuts in allocations to line ministries, agricultural subsidies, and health care expenditures. ${ }^{2}$ The scoring of some of the measures is inevitably uncertain, particularly the better targeting of disability pensions (relying on stricter enforcement of existing rules) and the reduction in energy subsidies (linked to prices). The higher deficit will be financed by greater use of official financing from the EU and the World Bank (Table 7).

\section{There are important risks to achieving the program targets for 2009. First,} growth, inflation, and interest payments could turn out less favorably than currently forecast, negatively affecting the overall fiscal balance. Second, tax revenue may underperform as

\footnotetext{
${ }^{2}$ A supplementary budget is not needed as the planned reduction in spending does not exceed the 5 percent threshold.
} 
compliance may decline during the crisis. Third, there are implementation risks, including with regard to spending cuts in public health institutions and reductions in farm subsidies. In view of these risks, the program includes a contingency buffer of 0.3 percent of GDP in the budget. With respect to 2010-11, further measures will be required to attain the fiscal consolidation envisaged under the program.

\section{The comprehensive tax reform aimed at shifting the tax burden from labor to} consumption and encouraging job creation is expected to be revenue neutral (LOI $\uparrow 16$ ). These initiatives, which also include tax-broadening measures, are in line with past staff advice. They are expected to be enacted by June 2009 and mostly come into force on July 1, 2009. Along with the structural spending cuts discussed above, they should provide a welcome boost to labor market participation over the medium term. Additional tax measures along the same lines are expected for 2011, including a new proposal for a central property tax to gradually replace inefficient and uneven local property taxes.

\section{Parliament adopted the Fiscal Responsibility Law in November 2008 (structural} benchmark) and the Fiscal Council has now been appointed (LOI 911 ). By subjecting budget preparation to fiscal rules aimed at reducing public debt and limiting expenditure growth, the law provides important institutional underpinnings to fiscal discipline. The newly appointed Fiscal Council will enhance external scrutiny on fiscal policy design and implementation. The authorities are committed to provide appropriate funding for the Fiscal Council.

\section{Financial Sector Policies}

\section{Banks' forint liquidity positions have improved and capital positions remain} well above regulatory requirements (Table 8 and LOI $\{17$ ). Parent banks increased funding of their Hungarian subsidiaries in October and November, and have since maintained their exposures, though the average maturity of such funding has shortened. Deposits have increased, which banks have used to acquire liquid assets. Conditions in the foreign exchange swap market have eased somewhat, though maturities remain short. Although nonperforming loans at end-2008 were still low (2.9 percent of gross loans), banks increased loan loss provisions sharply, resulting in a marked deterioration in profitability in 2008Q4. Hungary's largest bank, which does not have a foreign parent, increased its (consolidated) capital adequacy ratio to 15.3 percent (Tier I to 11.2 percent).

\section{Going forward, risks to financial stability are increasing with the economic} downturn and continued external financing difficulties. External funding will likely remain expensive and constrained, increasing rollover risk, especially for banks without a strong foreign parent. Similarly, the foreign currency swap market continues to be volatile and vulnerable to shocks, thus hampering banks' capacity to hedge their currency mismatch. Rising unemployment and corporate defaults will increase loan delinquencies. The exchange rate depreciation has increased the debt service burden of foreign currency loans (more than 
70 percent of loans to households are denominated in foreign currencies, notably Swiss francs). A substantial further weakening of the exchange rate could trigger a significant deterioration in banks' asset quality. The main domestic bank is also vulnerable to developments in its Central and Eastern European subsidiaries. Profitability will fall sharply, reflecting higher funding costs and more loan-loss provisions.

19. To improve the assessment of risks, the authorities will develop an action plan to strengthen the HFSA's capabilities in the area of on-site bank examinations. This plan will be developed by end-May 2009 (structural benchmark). The HFSA will conduct more comprehensive reviews of banks' end-2008 financial reports, and is planning expanded onsite inspections starting in the second quarter of 2009, with support from the World Bank. The HFSA will also strengthen cooperation with supervisors in countries where Hungarian banks have subsidiaries.

20. Given these risks, the government has enacted a bank support law with provisions for increasing capital and providing guarantees for borrowing (LOI $918-22$ ). The Financial Stability Act, which was approved by Parliament in December 2008, allows the government to grant guarantees for banks' newly issued debt and enhance banks' capital base by either voluntary or mandatory means (LOI 918 ). Conditions attached to these schemes include limits on management compensation and the issuance of a preferred share to the state with veto rights. The European Commission recently confirmed that both schemes are in line with EU state aid rules.

21. The program contains measures to preserve the continuity of the safety net for banks. Regarding the capital enhancement scheme, the deadline for applications will be extended from end-March 2009 to end-2009. The conditions under which a mandatory capital enhancement can occur will be clarified. Public resources will be protected by strengthening the provisions regarding the government's acquisition of shareholders' stakes. Regarding the bank borrowing guarantee scheme, an obstacle is how to ensure a high credit rating for the guarantee when the sovereign's credit rating is lower. Given the possibility of immediate funding needs, the authorities have decided to allow the government to lend directly to banks. Such loans and their pricing are expected to be in line with EU guidelines. The authorities and staff agreed on the importance of appropriate safeguards, including a government seat on the bank's board and access to information, along with enhanced monitoring by a sub-committee of the Financial Stability Committee (which includes the Ministry of Finance, the central bank, and the HFSA). The establishment of such a subcommittee to monitor bank support from the government is a structural performance criterion for end-March 2009 and the sub-committee's consultation with Fund staff on its work program is a continuous structural benchmark.

22. The remedial action and resolution regimes for banks are being strengthened (LOI 919-20). In December 2008, the authorities established new emergency powers for the HFSA and proposed changes to the remedial action framework (structural benchmark). The 
HFSA can now impose additional reporting requirements on banks in case the stability of the financial system is threatened, and, once the additional changes are adopted, will be able to intervene with extraordinary measures at a higher bank capital adequacy ratio than before (4.8 percent versus 4.0 percent). Moreover, the HFSA will have new powers to intervene in subsidiaries whose parent banks are in severe financial difficulties. Going forward, the powers of the HFSA and the special administrator appointed to manage a troubled bank will be broadened to facilitate efficient and cost effective bank resolution (structural benchmark for end-June 2009), though the extent of these changes is constrained by the strong protection of shareholders' rights under Hungary's constitutional framework.

\section{The program includes measures to facilitate loan restructuring without} undermining credit discipline (LOI $\mid 22$ ). The government and banks have extended until the end of 2009 the November 2008 voluntary agreement that outlines various options, including loan maturity extensions, a temporary easing of repayments, and a conversion of foreign currency loans into forint. Borrowers' interest in these options was limited in late 2008, but has increased in early 2009. Parliament passed a law in early March to provide temporary state guarantees for mortgage payments of the unemployed. Work is under way to amend the corporate bankruptcy regime; a personal bankruptcy regime is at the concept stage.

\section{Monetary and Exchange Rate Policy}

\section{CPI inflation in December 2008 was 3.5 percent, compared to 5.1 percent}

projected under the original program. As a result, the lower inner band of the inflation consultation mechanism (4.1 percent) was breached, prompting a discussion with staff. The authorities and staff agreed that the more rapid-than-expected fall in inflation largely reflected welcome exogenous factors beyond the authorities' control, notably the fasterthan-expected decline in global energy prices.

\section{The central bank gradually reduced the policy rate between November and} January, partly reversing the sharp rate hike in October. Interest rates were raised by 300 bps in October, at a time of intense financial market stress. Between November and January, the policy rate was cut four times by 50 bps each time, reflecting the moderation of financial market stress, the fall in projected inflation, and policy rate reductions by the major central banks. The policy rate was kept unchanged in February.

\section{Looking forward, monetary and exchange rate policy aims to prevent too rapid} a fall in inflation while safeguarding financial stability. With actual inflation now close to the central bank's medium-term inflation objective of 3 percent, the mid-point targets under the inflation consultation mechanisms have been set at 3.0 percent for all review dates in 2009, even though this is below the inflation forecast (LOI 923 ). While declining inflation and the widening output gap would suggest further monetary policy easing, overly rapid rate cuts could provoke excessive exchange rate depreciation (i.e., not justified by economic 
fundamentals). Given balance sheet effects associated with the nonfinancial sector's large, unhedged foreign currency borrowing, this could lead to financial market instability. Thus, any further interest rate cuts should be gradual and cautious, and commensurate with improvements in investor confidence. Moreover, the central bank stands ready to take action if necessary to mitigate the risk of disruptive movements in the exchange rate.

27. The central bank has introduced new facilities to improve liquidity provision in both domestic and foreign currency and strengthen banks' incentives to lend to the economy (Figure 3, and LOI 925 ). In addition to various short-term instruments, the central bank set up a temporary 6-month FX swap facility in early March, open to banks that maintain or expand long-term external funding and maintain their current level of lending to the corporate sector. Seven banks applied for the facility, including four of the six largest subsidiaries of foreign parent banks. In addition, a 3-month FX swap facility was put in place, which is priced at least 50 bps above the 6-month facility.

\section{Program Modalities And Safeguards Assessment}

\section{The attached Letter of Intent describes the authorities' progress in} implementing their economic program and sets out conditionality through June 2009 (Box 2, LOI $\mid 2$, and LOI Tables 1-2).

- $\quad$ Some modifications to the program's conditionality are proposed. The performance criterion for net international reserves would be adjusted upward to lock in the higher-than-programmed end-December outcome, as an additional buffer against a potential deterioration in external financing conditions. The inflation consultation bands would be set around the central bank's inflation target.

- $\quad$ Three new structural performance criteria and three new structural benchmarks are proposed. The performance criteria are the submission to parliament of (i) legislative changes to implement the pension reform and (ii) amendments to the Financial Stability Act; and (iii) establishment of a sub-committee of the tripartite Financial Stability Committee to monitor the financial soundness and stress-resilience of banks that receive capital of refinancing support from the government, all by endMarch 2009. Structural benchmarks would be the development of an action plan to strengthen the operational capabilities of the HFSA in the field of on-site bank examinations (end-May 2009), passage by parliament of the amendments strengthening the remedial powers of the HFSA and bank resolution regime (endJune 2009), and operation of the new-subcomittee described above as long as there is government capital or funding support outstanding to banks, and consultation of the sub-committee with Fund staff on its work program (continuous).

- $\quad$ No changes are proposed to the level of access or the schedule of purchases (Tables 8-10). 
Figure 3. Hungary: Monetary Policy Indicators, 2008-09
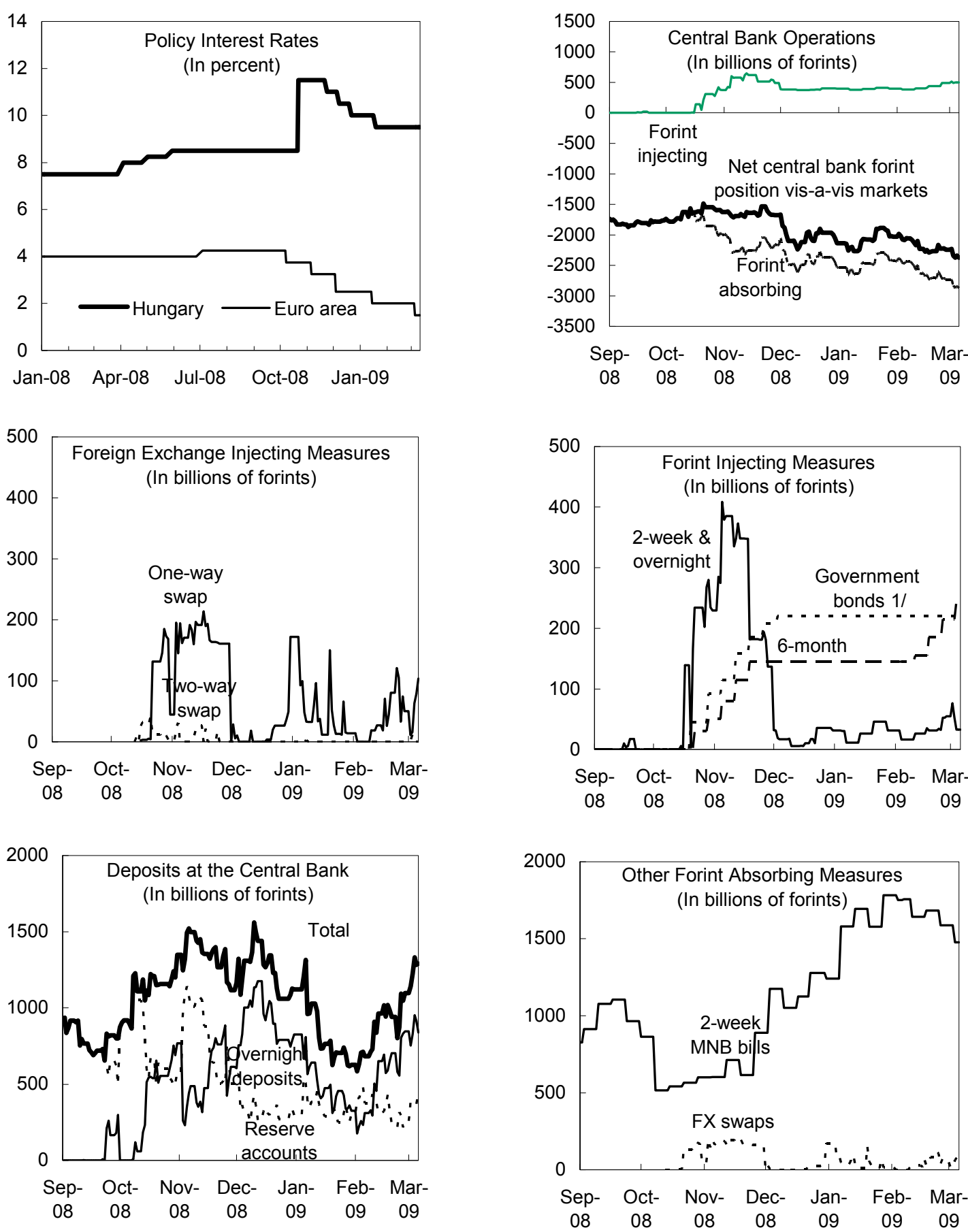

Sources: Hungarian authorities; and IMF staff calculations.

1/ Facility to purchase government bonds from primary dealers. 


\section{Box 2. Hungary: Stand-By Arrangement}

Access: SDR 10.5 billion (1015 percent of quota).

Length: 17 months (through end-March 2010).

Phasing: SDR 4.2 billion was made available after the Board's approval of the arrangement on November 6, 2008. The second tranche, subject to the completion of this (first) review, amounts to SDR 2.1 billion. Subsequent disbursements are contingent upon completion of further quarterly reviews.

\section{Conditionality}

- $\quad$ Quantitative Performance Criteria

$>$ A floor on the central government system primary cash balance.

$>$ A band around the 12-month rate of inflation of consumer prices

$>$ A floor on the change in net international reserves.

$>$ Non-accumulation of external debt arrears.

- $\quad$ Quantitative Indicative Target

$>$ Ceiling on the total debt stock of the central government system.

\section{- $\quad$ Structural Performance Criteria}

$>$ Submission to parliament of all legislative changes required to implement the measures on pension reforms (as described in LOI $\llbracket 15$, first bullet point). By end-March 2009.

$>$ Submission to parliament of amendments to the Financial Stability Act (as listed in LOI ๆ18). By end-March 2009.

$>$ Establishment of a subcommittee of the Financial Stability Committee to monitor the financial soundness and stress-resilience of banks that receive capital or funding support from the government (as described in LOI $\llbracket 18$ ). By end-March 2009.

- $\quad$ Structural Benchmarks

$>$ Passage by parliament of the amendments strengthening the remedial powers of the HFSA and bank resolution regime (as listed in LOI -20). By end-June 2009.

$>$ Development of an action plan to strengthen the operational capabilities of the HFSA in the field of on-site bank examinations. By end-May 2009.

$>$ Operation of the subcommittee described in LOI $\uparrow 18$ as long as there is any government capital or funding support outstanding to banks, and consultation of the subcommittee with Fund staff on its work program. Continuous.

- $\quad$ The safeguards assessment for the central bank was finalized in January 2009. The assessment confirms that the central bank has a relatively strong safeguards framework in place. The central bank's control environment is well established and the audit and financial reporting practices adhere to international standards. At the same time, the assessment recommends measures to improve the process of program data reporting to the Fund and to strengthen audit oversight. The authorities have already taken steps to these ends, in line with the proposed timeline. 


\section{Staff Appraisal}

29. Policy implementation has been largely in line with the program. The quantitative performance criteria and indicative target, and the structural performance criterion and benchmarks, for 2008Q4 were all met. CPI inflation in December 2008 was below the lower inner band, largely reflecting welcome exogenous developments beyond the authorities' control, notably the faster-than-expected decline in global energy prices.

\section{Looking forward, the continued strains in global financial markets and the} worse macroeconomic outlook pose significant challenges. Financial strains are still high and external financing remains difficult, reflecting in part ongoing global deleveraging. At the same time, the sharper global downturn is exacerbating the recession in Hungary, which will weaken government revenue and banks' credit quality. Against this background, strengthened policies are critical to support external financing and economic activity in Hungary.

\section{The revised program contains measures that aim to strengthen fiscal} sustainability while avoiding an excessively large negative impulse to demand. Structural measures, including pension reform, will yield a permanent reduction in government spending over the medium term. This is essential given Hungary's high level of government debt and the continued fragility of external financing conditions. The tax reform appropriately shifts the tax burden from labor to consumption and wealth, while being revenue neutral. This will reduce the tax wedge on labor and thus boost potential growth over the medium term. In response to the weaker outlook for government revenue in 2009, the program includes immediate spending cuts to ensure a substantial reduction in the headline fiscal deficit between 2008 and 2009, while allowing the projected fiscal deficit to rise somewhat relative to the original program. A temporary slowing of headline fiscal consolidation should not be detrimental to market confidence as it is accompanied by measures that give assurance about future adjustment. The progress in establishing the fiscal council is important in providing independent scrutiny of budget preparation and execution.

\section{It is essential that the authorities implement the measures to help preserve} financial stability contained in the revised program. While banks currently report adequate forint liquidity and strong capital positions, pressures will rise as a result of increased funding costs, the impact of the downturn on credit quality, continued difficult external financing conditions, and developments in countries where Hungarian banks have subsidiaries. To address these risks, the new Financial Stability Act, which includes capital enhancement and borrowing guarantee schemes for banks, has been put in place. Under the program, the government will introduce some technical amendments to this law to preserve the continuity of the safety net for banks and to better protect public resources. At the same time, the authorities will enact legislation to further strengthen the bank resolution regime and remedial action powers of the HFSA, and develop an action plan to improve its operational capabilities. 
33. Monetary and exchange rate policy will continue to target inflation over the medium term, while being prepared to act as needed to mitigate risks to financial stability. In light of the fall in projected inflation, the reductions in the policy interest rate thus far have been appropriate. Looking forward, any further interest rate cuts should be gradual and cautious, and commensurate with improvements in investor confidence. The central bank is ready to take action if necessary to mitigate the risk of disruptive movements in the exchange rate. In addition, the central bank is ready to modify or expand its liquidityproviding facilities as needed.

34. The authorities' commitments provide a strong policy anchor, but risks remain. The new measures address Hungary's two most significant vulnerabilities: the high level of government debt and potential risks to the stability of the banking system. The path of underlying fiscal adjustment has been accelerated, and financial supervision and the safety net for banks are being strengthened. Yet risks to the program remain, including a more severe than currently projected economic downturn, the impact of continued stress in global financial markets on emerging market financing, and lack of necessary political support for key measures. To address these risks, the authorities recognize the need for continued careful program monitoring and for ongoing policy dialogue with the Fund, and are committed to make policy adjustments that may become necessary.

35. Implementation of policies consistent with the program provides the best chance for Hungary's economy to weather the current difficulties. Staff support the authorities' request for completion of the first review under the Stand-By Arrangement. 
Table 1. Hungary: Main Economic Indicators, 2005-09

\begin{tabular}{|c|c|c|c|c|c|c|c|}
\hline & \multirow[t]{2}{*}{2005} & \multirow[t]{2}{*}{2006} & \multirow[t]{2}{*}{2007} & \multicolumn{2}{|c|}{2008} & \multicolumn{2}{|c|}{2009} \\
\hline & & & & $\begin{array}{l}\text { Orig. } \\
\text { Prog. }\end{array}$ & Est. & $\begin{array}{l}\text { Orig. } \\
\text { Prog. }\end{array}$ & $\begin{array}{r}\text { Rev. } \\
\text { Prog. }\end{array}$ \\
\hline \multicolumn{8}{|l|}{ Real economy (change in percent) } \\
\hline Real GDP & 4.0 & 4.0 & 1.1 & 1.8 & 0.6 & -1.0 & -3.3 \\
\hline Private consumption & 3.6 & 1.9 & -1.8 & 0.9 & 0.6 & -3.9 & -3.8 \\
\hline Gross fixed investment & 8.0 & -5.7 & 1.5 & 1.0 & -2.4 & -0.9 & -5.0 \\
\hline Exports & 11.5 & 18.4 & 15.9 & 7.6 & 7.3 & 2.1 & -3.2 \\
\hline Imports & 6.9 & 15.0 & 13.1 & 8.1 & 6.7 & 0.7 & -4.3 \\
\hline CPI (end year) & 3.3 & 6.5 & 7.4 & 5.1 & 3.5 & 4.2 & 4.3 \\
\hline CPI (average) & 3.6 & 3.9 & 7.9 & 6.3 & 6.1 & 4.5 & 3.8 \\
\hline Unemployment rate (average, in percent) & 7.2 & 7.5 & 7.4 & 7.8 & 7.8 & 8.5 & 8.9 \\
\hline Gross domestic investment (percent of GDP) $1 /$ & 24.2 & 24.3 & 23.7 & 22.8 & 22.5 & 20.0 & 19.4 \\
\hline Gross national saving (percent of GDP, from BOP) & 16.7 & 16.7 & 17.2 & 16.5 & 14.7 & 18.0 & 15.4 \\
\hline \multicolumn{8}{|l|}{ General government (percent of GDP), ESA-95 basis 2/ } \\
\hline Overall balance & -7.8 & -9.3 & -4.9 & -3.4 & -3.3 & -2.5 & -2.9 \\
\hline Primary balance & -3.7 & -5.4 & -0.9 & 0.6 & 0.7 & 1.9 & 1.5 \\
\hline Debt & 61.7 & 65.6 & 65.8 & 67.4 & 72.2 & 70.1 & 75.9 \\
\hline \multicolumn{8}{|l|}{ Money and credit (end-of-period, percent change) } \\
\hline Broad money & 14.5 & 13.6 & 11.0 & 4.1 & 9.1 & 1.3 & 2.2 \\
\hline Credit to nongovernment, flow-based & 15.4 & 17.3 & 15.9 & $\ldots$ & 10.6 & $\ldots$ & -0.7 \\
\hline \multicolumn{8}{|l|}{ Interest rates (percent) } \\
\hline T-bill (90-day, average) & 6.7 & 7.0 & 7.6 & $\ldots$ & 8.9 & $\ldots$ & $\ldots$ \\
\hline Government bond yield (5-year, average) & 6.8 & 7.4 & 7.0 & $\ldots$ & 9.3 & $\ldots$ & $\ldots$ \\
\hline \multicolumn{8}{|l|}{ Balance of payments } \\
\hline Goods and services trade balance (percent of GDP) & -1.2 & -0.9 & 1.4 & 1.8 & 1.4 & 7.5 & 4.9 \\
\hline Current account (percent of GDP) & -7.5 & -7.5 & -6.4 & -6.2 & -7.8 & -2.0 & -3.9 \\
\hline Reserves (in billions of euros) & 15.7 & 16.4 & 16.4 & 19.5 & 24.0 & 19.8 & 22.4 \\
\hline Gross external debt (percent of GDP) 3/ & 75.0 & 90.4 & 97.2 & 106.4 & 114.4 & 115.8 & 131.1 \\
\hline \multicolumn{8}{|l|}{ Exchange rate } \\
\hline Exchange regime & \multicolumn{7}{|c|}{ Floating } \\
\hline Present rate (March 12, 2009) & \multicolumn{7}{|c|}{ Ft $239.07=$ US\$1; Ft. $305.67=€ 1$} \\
\hline Nominal effective rate $(2000=100)$ & 111.6 & 105.1 & 111.8 & $\ldots$ & 112.6 & $\cdots$ & $\ldots$ \\
\hline Real effective rate, CPI basis $(2000=100)$ & 132.6 & 127.0 & 142.5 & $\ldots$ & 147.2 & $\ldots$ & $\ldots$ \\
\hline Quota at the Fund & \multicolumn{7}{|c|}{ SDR 1038.4 million } \\
\hline
\end{tabular}

Sources: Hungarian authorities; IMF, International Financial Statistics; Bloomberg; and IMF staff estimates.

$1 /$ Includes change in inventories.

$2 /$ Consists of the central budget, social security funds, extrabudgetary funds, and local governments, as well as motorway investments previously expected to be recorded off-budget in 2006-07.

$3 /$ Including inter-company loans, and nonresident holdings of forint-denominated assets. 
Table 2. Hungary: Monetary Accounts, 2005-10

\begin{tabular}{|c|c|c|c|c|c|c|c|c|c|c|}
\hline & \multirow[t]{2}{*}{2005} & \multirow[t]{2}{*}{2006} & \multirow[t]{2}{*}{2007} & \multicolumn{2}{|c|}{2008} & \multicolumn{4}{|c|}{2009} & \multirow{2}{*}{$\begin{array}{l}2010 \\
\text { Proj }\end{array}$} \\
\hline & & & & \multicolumn{2}{|c|}{ Est. } & \multicolumn{4}{|c|}{ Proj. } & \\
\hline & \multicolumn{10}{|c|}{ (in billions of forints, unless otherwise specified) } \\
\hline \multicolumn{11}{|l|}{ Monetary Survey } \\
\hline Net foreign assets & 375 & -83 & -952 & -1597 & -1510 & -1191 & -1046 & -1051 & -1098 & -1413 \\
\hline Net domestic assets & 10830 & 12809 & 15078 & 16242 & 16926 & 16993 & 16748 & 16690 & 16853 & 17720 \\
\hline Domestic credit & 13711 & 16190 & 18907 & 20523 & 21366 & 21545 & 21243 & 21170 & 21304 & 22085 \\
\hline Net claims on government & 2426 & 3026 & 3270 & 3299 & 2836 & 2130 & 1954 & 1748 & 1875 & 2056 \\
\hline Credit to the economy & 11285 & 13165 & 15637 & 17224 & 18530 & 19416 & 19290 & 19423 & 19429 & 20029 \\
\hline Other items, net & -2881 & -3381 & -3829 & -4280 & -4440 & -4553 & -4495 & -4481 & -4450 & -4365 \\
\hline Broad money & 11204 & 12727 & 14126 & 14645 & 15416 & 15801 & 15702 & 15639 & 15755 & 16307 \\
\hline Currency in circulation & 1600 & 1838 & 2068 & 2009 & 2139 & 2161 & 2175 & 2190 & 2277 & 2483 \\
\hline Total deposits & 9053 & 10075 & 10869 & 11444 & 12108 & 12404 & 12292 & 12191 & 12195 & 12520 \\
\hline Domestic currency deposits & 7664 & 7827 & 8704 & 8656 & 9727 & 9879 & 9789 & 9708 & 9712 & 9971 \\
\hline Foreign currency deposits & 1388 & 2248 & 2165 & 2788 & 2381 & 2526 & 2470 & 2424 & 2408 & 2454 \\
\hline Short-term securities & 56 & 35 & 200 & 152 & 321 & 321 & 321 & 321 & 321 & 321 \\
\hline Money market instruments & 495 & 779 & 990 & 1039 & 848 & 915 & 913 & 937 & 963 & 983 \\
\hline \multicolumn{11}{|l|}{ Accounts of the Magyar Nemzeti Bank (MNB) } \\
\hline Net foreign assets $1 /$ & 3673 & 3838 & 3941 & 4046 & 5988 & 6016 & 5652 & 4901 & 4733 & 4204 \\
\hline Net domestic assets & -1473 & -1404 & -1150 & -1397 & -3383 & -3358 & -2982 & -2204 & -1950 & -1164 \\
\hline Net domestic credit & -1360 & -1369 & -1138 & -1561 & -3193 & -2866 & -2476 & -1693 & -1425 & -584 \\
\hline Net claims on government & -37 & -141 & -108 & -281 & -1286 & -1810 & -1934 & -1856 & -1854 & -1854 \\
\hline Claims on government & 247 & 233 & 147 & 147 & 360 & 366 & 366 & 314 & 314 & 314 \\
\hline Liabilities to government $2 /$ & 284 & 373 & 255 & 428 & 1646 & 2176 & 2300 & 2169 & 2168 & 2168 \\
\hline Net claims on the economy & -5 & -5 & 0 & 0 & 0 & 0 & 0 & 0 & 0 & 0 \\
\hline Net claims on banks & -1318 & -1223 & -1029 & -1280 & -1907 & -1056 & -542 & 163 & 429 & 1270 \\
\hline Other items, net & -113 & -34 & -12 & 164 & -190 & -492 & -507 & -511 & -524 & -580 \\
\hline Base money & 2199 & 2434 & 2791 & 2648 & 2605 & 2658 & 2670 & 2697 & 2784 & 3041 \\
\hline Currency in circulation & 1600 & 1838 & 2068 & 2009 & 2139 & 2161 & 2175 & 2190 & 2277 & 2483 \\
\hline Cash in bank vaults & 114 & 130 & 134 & 140 & 170 & 147 & 141 & 152 & 153 & 178 \\
\hline Banks' reserves & 485 & 466 & 589 & 500 & 296 & 350 & 353 & 355 & 355 & 380 \\
\hline Required reserves & 526 & 615 & 682 & 751 & 322 & 350 & 353 & 355 & 355 & 380 \\
\hline Excess reserves & -40 & -149 & -92 & -252 & -26 & 0 & 0 & 0 & 0 & 0 \\
\hline \multicolumn{11}{|l|}{ Other Monetary and Financial Institutions } \\
\hline Net foreign assets & -3298 & -3920 & -4892 & -5643 & -7498 & -7207 & -6699 & -5952 & -5832 & -5618 \\
\hline Net domestic assets & 12902 & 14809 & 16951 & 18279 & 20775 & 20848 & 20225 & 19401 & 19310 & 19441 \\
\hline Domestic credit & 15066 & 17554 & 20045 & 22084 & 24559 & 24411 & 23719 & 22863 & 22729 & 22668 \\
\hline Net claims on government & 2463 & 3166 & 3378 & 3580 & 4122 & 3939 & 3887 & 3603 & 3729 & 3910 \\
\hline Credit to the economy & 11285 & 13165 & 15637 & 17224 & 18530 & 19416 & 19290 & 19423 & 19429 & 20029 \\
\hline Net claims on the central bank & 1318 & 1223 & 1029 & 1280 & 1907 & 1056 & 542 & -163 & -429 & -1270 \\
\hline Banks' reserves and overnight deposits & 750 & 838 & 1062 & 798 & 296 & 350 & 353 & 355 & 355 & 380 \\
\hline Other items, net & -2914 & -3584 & -4156 & -4603 & -4080 & -3914 & -3848 & -3817 & -3773 & -3607 \\
\hline Banks' liabilities & 9604 & 10888 & 12058 & 12636 & 13277 & 13640 & 13526 & 13449 & 13479 & 13824 \\
\hline Total deposits & 9053 & 10075 & 10869 & 11444 & 12108 & 12404 & 12292 & 12191 & 12195 & 12520 \\
\hline Demand deposits & 3589 & 3995 & 4280 & 4107 & 4025 & 4124 & 4086 & 4052 & 4054 & 4162 \\
\hline Time deposits & 5464 & 6080 & 6589 & 7337 & 8083 & 8281 & 8206 & 8138 & 8141 & 8358 \\
\hline Short-term securities & 56 & 35 & 200 & 152 & 321 & 321 & 321 & 321 & 321 & 321 \\
\hline Money market instruments & 495 & 779 & 990 & 1039 & 848 & 915 & 913 & 937 & 963 & 983 \\
\hline Memorandum items : & \multicolumn{10}{|c|}{ (y-o-y percentage change) } \\
\hline Base money & 9.4 & 10.7 & 14.7 & 2.7 & -6.7 & 1.4 & 2.4 & 1.8 & 6.9 & 10.1 \\
\hline Broad money & 14.5 & 13.6 & 11.0 & 8.2 & 9.1 & 7.7 & 10.8 & 6.8 & 2.2 & 3.5 \\
\hline Credit to the economy & 18.9 & 16.7 & 18.8 & 16.1 & 18.5 & 16.3 & 19.3 & 12.8 & 4.9 & 3.1 \\
\hline Credit to the economy, flow-based $3 /$ & 0.0 & 17.3 & 15.9 & 15.3 & 10.6 & 5.0 & 2.0 & -1.0 & -0.7 & 3.1 \\
\hline & & & & & (in perc & & & & & \\
\hline Foreign currency loans to total loans & 45.2 & 47.9 & 56.4 & 58.7 & 64.7 & 67.0 & 67.2 & 67.6 & 68.4 & 68.0 \\
\hline Foreign currency deposits to total deposits & 15.3 & 22.3 & 19.9 & 24.4 & 19.7 & 20.4 & 20.1 & 19.9 & 19.7 & 19.6 \\
\hline & & & & & billions o & forints) & & & & \\
\hline Net international reserves & 3769 & 4007 & 4057 & 4157 & 4897 & 4793 & 3803 & 3052 & 2884 & 2355 \\
\hline plus IMF disbursement to the government 4 / & 0 & 0 & 0 & 0 & 1215 & 1331 & 1331 & 1331 & 1331 & 1331 \\
\hline plus bank guarantee fund $5 /$ & 0 & 0 & 0 & 0 & 0 & 0 & 626 & 626 & 626 & 626 \\
\hline minus other non-reserve liabilities (net) & 96 & 169 & 116 & 112 & 124 & 107 & 108 & 108 & 108 & 108 \\
\hline$=$ net foreign assets of the central bank & 3673 & 3838 & 3941 & 4046 & 5988 & 6016 & 5652 & 4901 & 4733 & 4204 \\
\hline
\end{tabular}

Sources: Magyar Nemzeti Bank and IMF staff calculation

1/ Includes disbursement of the first IMF tranche under the SBA to the government, as well as disbursements of EU and WB funds.

2/ Includes built-up of government deposits commensurate with the disbursement of the first IMF tranche, EU and WB funds; as well as the use of deposits to finance the government's net borrowing requirements.

3/ Controls for fluctuations in the exchange rate.

4/ The first IMF tranche under the SBA was disbursed to the government. All subsequent tranches are scheduled to be disbursed to the MNB.

$5 /$ Encumbered assets, do not count as reserves. 
Table 3. Hungary: Balance of Payments, 2007-10 (In millions of euros)

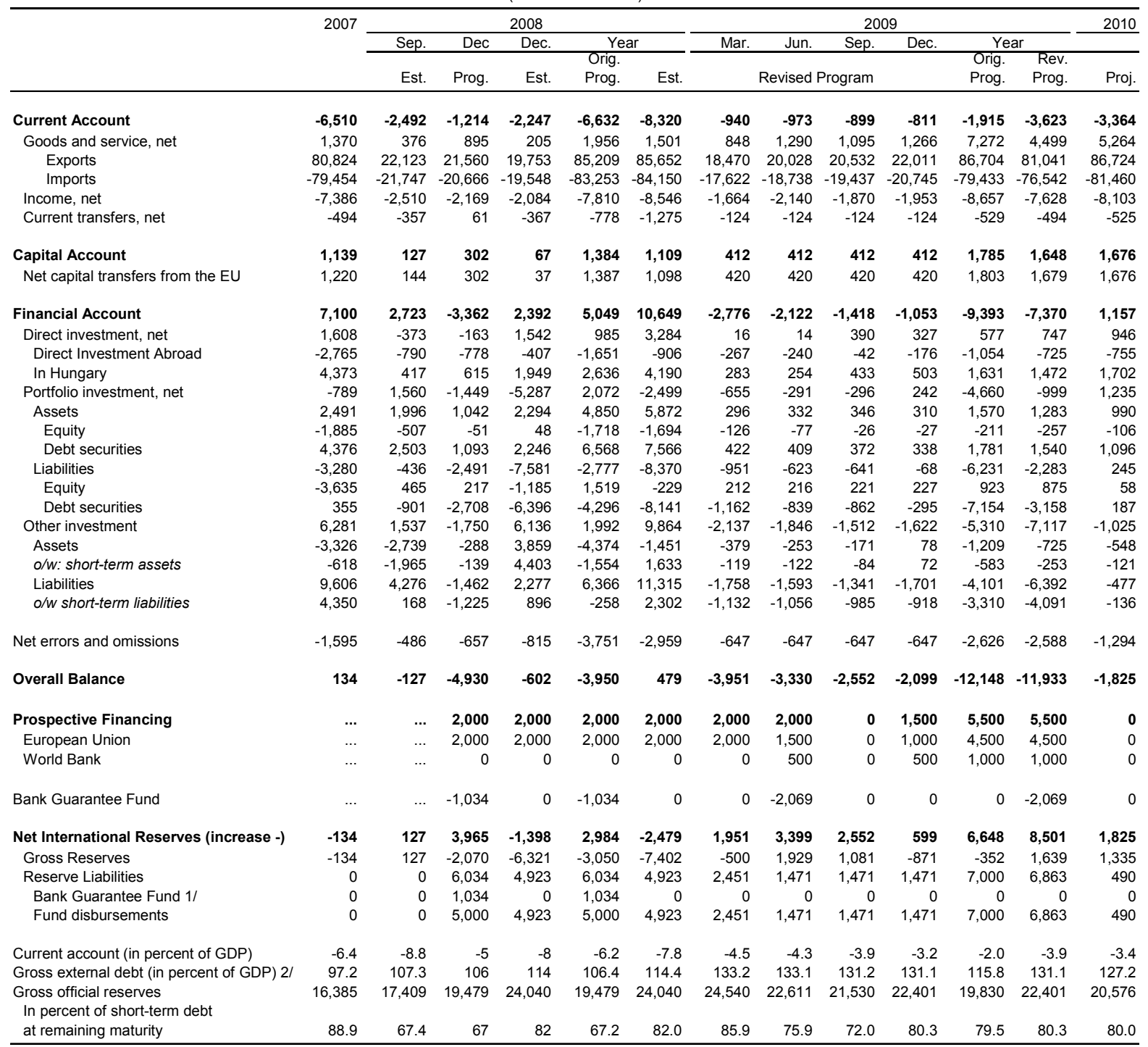

Sources: Hungarian authorities and IMF staff projections.

1/ The Reserve Guarantee Fund was included both in reserve assets and liabilities at program approval, but is now expected to be separated from gross reserves. 2/ Includes inter-company loans-estimated at 21.4 percent of GDP at end-2008-and non-resident holdings of forint-denominated assets. 
Table 4. Hungary: Indicators of External Vulnerability, 2005-08

\begin{tabular}{|c|c|c|c|c|}
\hline & 2005 & 2006 & 2007 & $\begin{array}{r}2008 \\
\text { Est. }\end{array}$ \\
\hline \multicolumn{5}{|l|}{ Financial Indicators } \\
\hline M3, end-of-period, percent change & 14.5 & 13.6 & 11.0 & 9.1 \\
\hline Credit to nongovernment, flow-based & 15.4 & 17.3 & 15.9 & 10.6 \\
\hline T-bill , 90-day, average, in percent & 6.7 & 7.0 & 7.6 & 8.9 \\
\hline Government bond yield, 5-year, average, in percent & 6.8 & 7.4 & 7.0 & 9.3 \\
\hline Share of foreign currency liabilities in total liabilities & 34.4 & 39.3 & 42.4 & 42.0 \\
\hline \multicolumn{5}{|l|}{ Share of foreign currency loans in total credit to: $1 /$} \\
\hline Corporates & 47.7 & 47.1 & 52.6 & 60.3 \\
\hline Households & 32.6 & 46.8 & 59.0 & 70.7 \\
\hline Other loans & 75.2 & 75.4 & 81.7 & 87.2 \\
\hline Non-performing loans to gross loans $2 /$ & 2.5 & 2.5 & 2.5 & 2.9 \\
\hline \multicolumn{5}{|l|}{ External Indicators } \\
\hline Exports of goods and services, annual percentage change & 12.9 & 15.0 & 17.1 & 6.0 \\
\hline Imports of goods and services, annual percentage change & 10.0 & 14.2 & 13.8 & 5.9 \\
\hline Real effective exchange rate, percentage change, $+=$ appreciation & 2.0 & -4.5 & 19.4 & .. \\
\hline Current account balance, in percent of GDP & -7.5 & -7.5 & -6.4 & -7.8 \\
\hline Capital and financial account, in percent of GDP & 0.8 & 0.6 & 1.1 & 1.0 \\
\hline Financial account, in percent of GDP & 13.0 & 10.3 & 7.0 & 10.0 \\
\hline Net foreign direct investment, in percent of GDP & 5.0 & 3.2 & 1.6 & 3.1 \\
\hline Gross official reserves, in millions of euros & 15,721 & 16,397 & 16,385 & 24,040 \\
\hline In months of imports & 2.7 & 2.5 & 2.3 & 3.8 \\
\hline In percent of short-term debt at remaining maturity & 112.2 & 123.6 & 88.9 & 82.0 \\
\hline Total external debt, in millions of euros & 66,608 & 81,428 & 98,266 & 121,616 \\
\hline In percent of GDP & 75.1 & 90.5 & 97.2 & 114.4 \\
\hline Short-term debt at remaining maturity, in millions of euros & 14,012 & 13,270 & 18,428 & 29,304 \\
\hline \multicolumn{5}{|l|}{ Financial Market Indicators } \\
\hline Stock market index, local currency, end-of-period & 20,785 & 24,844 & 26,236 & 12,242 \\
\hline EMBI Global bonds spread, end-of-period & 74.0 & 58.0 & 84.0 & 504.0 \\
\hline CDS spread, 5-year, end-of-period & 26.5 & 21.0 & 48.5 & 430.2 \\
\hline
\end{tabular}

Source: Hungarian authorities; and staff estimates.

1/ Country Report No. 08/361 cited the share of foreign currency loan in total credit. The corresponding values for 2008 are corporates (21.3 percent), households (25.4 percent) and other loans (25 percent). $2 /$ Non-performing loans are defined as loans past due more than 90 days. 
Table 5. Hungary: Staff's Illustrative Medium-Term Scenario, 2005-11

\begin{tabular}{|c|c|c|c|c|c|c|c|}
\hline & 2005 & 2006 & 2007 & 2008 & 2009 & 2010 & 2011 \\
\hline & & & & Est. & \multicolumn{3}{|c|}{ Program } \\
\hline & \multicolumn{7}{|c|}{ (In percent, unless otherwise indicated) } \\
\hline Real GDP growth & 4.0 & 4.0 & 1.1 & 0.6 & -3.3 & -0.4 & 2.5 \\
\hline Nominal GDP, forint billions & 21,997 & 23,785 & 25,419 & 26,700 & 26,640 & 27,323 & 28,846 \\
\hline Inflation (CPI; year average basis) & 3.6 & 3.9 & 7.9 & 6.1 & 3.8 & 2.8 & 3.0 \\
\hline \multirow[t]{2}{*}{ Inflation (CPI; end-year basis) } & 3.3 & 6.5 & 7.4 & 3.5 & 4.3 & 2.8 & 3.0 \\
\hline & \multicolumn{7}{|c|}{ (Annual percentage change, constant prices) } \\
\hline Domestic demand & 0.5 & 1.3 & -1.8 & -0.4 & -4.7 & -1.7 & 2.0 \\
\hline Consumption & 3.2 & 2.4 & -1.8 & 0.6 & -3.7 & -0.8 & 1.0 \\
\hline Gross fixed capital formation & 8.0 & -5.7 & 1.5 & -2.4 & -5.0 & 1.1 & 5.0 \\
\hline Exports of GNFS & 11.5 & 18.4 & 15.9 & 7.3 & -3.2 & 3.8 & 4.6 \\
\hline \multirow[t]{2}{*}{ Imports of GNFS } & 6.9 & 15.0 & 13.1 & 6.7 & -4.3 & 3.0 & 4.3 \\
\hline & \multicolumn{7}{|c|}{ (In percent of GDP, unless otherwise indicated) } \\
\hline External current account balance & -7.5 & -7.5 & -6.4 & -7.8 & -3.9 & -3.4 & -3.1 \\
\hline Gross national saving & 16.7 & 16.7 & 17.2 & 14.7 & 15.4 & 15.8 & 16.9 \\
\hline Gross national investment $1 /$ & 24.2 & 24.3 & 23.7 & 22.5 & 19.4 & 19.2 & 20.1 \\
\hline Capital account, net & 0.8 & 0.6 & 1.1 & 1.0 & 1.8 & 1.7 & 1.6 \\
\hline Financial account, net & 12.9 & 10.3 & 7.0 & 10.0 & -8.0 & 1.2 & 3.2 \\
\hline Gross external debt $2 /$ & 75.0 & 90.4 & 97.2 & 114.4 & 131.1 & 127.2 & 123.1 \\
\hline \multicolumn{8}{|l|}{ General government (ESA-95) } \\
\hline Revenue, primary & 42.0 & 42.3 & 44.6 & 45.6 & 46.3 & 45.7 & 45.5 \\
\hline Expenditure, primary & 46.0 & 48.0 & 45.8 & 45.1 & 45.0 & 43.9 & 43.5 \\
\hline Primary balance & -3.7 & -5.4 & -0.9 & 0.7 & 1.5 & 2.0 & 2.2 \\
\hline General government balance (incl. costs of pension reform) & -7.8 & -9.3 & -4.9 & -3.3 & -2.9 & -2.5 & -2.2 \\
\hline Net interest & 3.9 & 3.7 & 3.8 & 3.8 & 4.1 & 4.2 & 4.0 \\
\hline General government debt & 61.7 & 65.6 & 65.8 & 72.2 & 75.9 & 72.2 & 69.0 \\
\hline \multicolumn{8}{|l|}{ Memorandum items } \\
\hline Output gap & 0.6 & 2.0 & 1.0 & -0.4 & -5.8 & -8.3 & -8.0 \\
\hline Potential GDP growth & 3.5 & 2.6 & 2.1 & 2.0 & 2.0 & 2.1 & 2.2 \\
\hline Structural general government balance & -8.1 & -7.1 & -4.5 & -3.4 & 0.0 & 1.1 & 0.9 \\
\hline Structural primary balance & -4.3 & -3.4 & -0.7 & 0.4 & 4.1 & 5.4 & 4.9 \\
\hline
\end{tabular}

Sources: Hungarian authorities; and IMF staff projections.

$1 /$ Includes change in inventories.

2/ Includes intercompany loans.

3 / Consistent with the balance of payments data (not necessarily with the national accounts data). 
Table 6. Hungary: Consolidated General Government, 2006-11 $1 /$ (In percent of GDP, unless otherwise indicated)

\begin{tabular}{|c|c|c|c|c|c|c|c|c|}
\hline & \multirow[t]{2}{*}{2006} & \multirow[t]{2}{*}{2007} & \multicolumn{2}{|c|}{2008} & \multicolumn{2}{|c|}{2009} & \multirow{2}{*}{\multicolumn{2}{|c|}{$\begin{array}{c}2010 \quad 2011 \\
\text { Convergence } \\
\text { Program 2/ }\end{array}$}} \\
\hline & & & $\begin{array}{l}\text { Orig. } \\
\text { Prog. }\end{array}$ & Est. & $\begin{array}{c}\text { Budget } \\
\text { Auth. }\end{array}$ & $\begin{array}{l}\text { Rev. } \\
\text { Prog. }\end{array}$ & & \\
\hline Total revenues & 42.6 & 44.9 & 45.3 & 45.9 & 45.8 & 46.5 & 46.0 & 45.8 \\
\hline Current revenues and current transfers (incl. grants) & 41.7 & 44.0 & 44.1 & 44.9 & 44.2 & 44.8 & 43.9 & 43.5 \\
\hline Tax revenues & 37.0 & 39.5 & 39.8 & 40.5 & 40.0 & 40.4 & 39.9 & 39.8 \\
\hline Taxes on income, profits and capital gains & 9.4 & 10.2 & 10.5 & 10.7 & 10.8 & 10.5 & 10.9 & 11.0 \\
\hline Personal income tax & 6.7 & 7.1 & 7.4 & 7.6 & 7.6 & 7.4 & 7.8 & 8.0 \\
\hline Corporate income tax & 2.3 & 2.8 & 2.7 & 2.7 & 2.8 & 2.7 & 2.8 & 2.7 \\
\hline Other (incl. wealth, capital, and property taxes) & 0.4 & 0.4 & 0.4 & 0.4 & 0.3 & 0.4 & 0.3 & 0.4 \\
\hline Taxes on payroll and workforce and Social Security contributions & 12.6 & 13.6 & 13.8 & 14.0 & 13.7 & 13.7 & 13.8 & 13.8 \\
\hline Taxes on goods and services & 15.0 & 15.6 & 15.5 & 15.8 & 15.4 & 16.1 & 15.2 & 14.9 \\
\hline VAT & 7.4 & 7.8 & 7.7 & 7.8 & 7.6 & 8.2 & 7.5 & 7.4 \\
\hline Other (incl. excises and import taxes) & 7.5 & 7.9 & 7.8 & 8.0 & 7.8 & 7.9 & 7.7 & 7.5 \\
\hline Current non-tax revenues & 4.0 & 3.8 & 3.6 & 3.9 & 3.7 & 3.9 & 3.4 & 3.2 \\
\hline Of which: interest & 0.3 & 0.3 & 0.3 & 0.3 & 0.2 & 0.2 & 0.3 & 0.3 \\
\hline Current transfers (incl. grants) & 0.8 & 0.6 & 0.7 & 0.5 & 0.6 & 0.6 & 0.6 & 0.6 \\
\hline Capital revenues and capital transfers (incl. grants) & 0.9 & 0.9 & 1.2 & 1.0 & 1.6 & 1.7 & 2.1 & 2.2 \\
\hline Memorandum item: subnational governments own revenues & 6.3 & 5.9 & - & - & - & - & - & - \\
\hline Total expenditures & 51.9 & 49.8 & 48.7 & 49.2 & 48.4 & 49.3 & 48.5 & 48.0 \\
\hline Current expenditures and current transfers & 45.7 & 44.3 & 44.0 & 44.3 & 43.8 & 44.5 & 43.2 & 42.4 \\
\hline Compensation of employees $3 /$ & 12.1 & 11.5 & 11.3 & 11.6 & 10.9 & 11.3 & 10.9 & 10.7 \\
\hline Goods and services & 7.0 & 6.7 & 6.6 & 6.5 & 6.6 & 6.5 & 6.4 & 6.2 \\
\hline Interest payments & 4.0 & 4.0 & 4.0 & 4.0 & 4.5 & 4.3 & 4.5 & 4.5 \\
\hline Subsidies & 1.4 & 1.4 & 1.4 & 1.2 & 1.0 & 0.8 & 0.9 & 0.8 \\
\hline Current transfers to households & 18.5 & 18.1 & 18.3 & 18.6 & 18.5 & 19.1 & 18.1 & 17.6 \\
\hline Social security & 13.5 & 13.5 & - & 14.4 & 14.3 & 14.8 & 14.1 & 13.9 \\
\hline Of which unemployment benefits & 0.4 & 0.4 & - & 0.4 & 0.4 & 0.4 & 0.4 & 0.4 \\
\hline Other & 5.0 & 4.6 & - & 4.3 & 4.2 & 4.3 & 4.1 & 3.7 \\
\hline Other current transfers & 2.7 & 2.6 & 2.5 & 2.3 & 2.3 & 2.4 & 2.4 & 2.5 \\
\hline Capital expenditures & 4.3 & 3.6 & 3.1 & 2.9 & 3.0 & 3.2 & 3.4 & 3.6 \\
\hline Capital transfers & 1.9 & 1.9 & 1.5 & 2.1 & 1.6 & 1.7 & 1.8 & 2.0 \\
\hline Other net expenditure & - & - & - & - & - & - & - & - \\
\hline Memorandum item: subnational governments total expenditure & 12.8 & 11.6 & - & - & - & - & - & - \\
\hline General government balance & -9.3 & -4.9 & -3.4 & -3.3 & -2.6 & -2.9 & -2.5 & -2.2 \\
\hline Primary balance & -5.4 & -0.9 & 0.6 & 0.7 & 1.9 & 1.5 & 2.0 & 2.2 \\
\hline \multicolumn{9}{|l|}{ Memorandum items: } \\
\hline Primary expenditure & 48.0 & 45.8 & 44.7 & 45.1 & 43.9 & 45.0 & 43.9 & 43.5 \\
\hline Output gap (in percent of potential GDP) & 2.0 & 1.0 & -0.9 & -0.4 & -3.1 & -5.8 & -3.8 & -3.6 \\
\hline Cyclically-adjusted overall balance (CAB, in percent of potential GDP) & -10.4 & -5.4 & -3.0 & -3.1 & -1.8 & 0.0 & -1.5 & -1.3 \\
\hline Change in $\mathrm{CAB}$ & -2.2 & 4.9 & 2.0 & 2.3 & 1.6 & 3.1 & 0.3 & 0.2 \\
\hline One-off items (net) & -3.3 & -1.0 & 0.1 & 0.2 & 0.0 & 0.0 & 0.0 & 0.0 \\
\hline Structural balance & -7.1 & -4.5 & -3.1 & -3.4 & -1.8 & 0.0 & -1.5 & -1.3 \\
\hline Change in the structural balance & - & 2.6 & 0.9 & 1.1 & 1.2 & 3.3 & 0.3 & 0.2 \\
\hline Gross public debt & 65.6 & 65.8 & 67.4 & 72.2 & 72.5 & 75.9 & 72.2 & 69.0 \\
\hline Real GDP growth (in percent) & 4.0 & 1.1 & 1.8 & 0.6 & -0.9 & -3.3 & 1.6 & 2.5 \\
\hline \multicolumn{9}{|l|}{ In nominal terms (HUF billions) } \\
\hline Total revenues & 10,133 & 11,411 & 12,317 & 12,243 & 12,993 & 12,381 & 13,363 & 14,039 \\
\hline Total expenditure & 12,350 & 12,666 & 13,246 & 13,129 & 13,818 & 13,141 & 14,086 & 14,717 \\
\hline Primary balance & $-1,276$ & -227 & 81 & 192 & 372 & 389 & 589 & 687 \\
\hline General government balance & $-2,217$ & $-1,256$ & -929 & -886 & -824 & -759 & -723 & -678 \\
\hline
\end{tabular}

Sources: Hungarian authorities; and staff estimates.

1/ Data are classified following the ESA'95 methodology, as reported to the European Commission.

2/ Based on the Hungarian authorities' Updated Convergence Program, 2008-2011, published in December 2008.

$3 /$ Including social security contributions. 
Table 7. Hungary. Borrowing Requirement of the Central Government, 2008-09 (in billion of forints)

\begin{tabular}{|c|c|c|c|c|c|c|c|c|c|c|}
\hline & \multicolumn{4}{|c|}{2008} & \multicolumn{6}{|c|}{2009} \\
\hline & \multicolumn{2}{|c|}{ Q4 } & \multicolumn{2}{|c|}{ Year } & Q1 & & Q3 & Q4 & \multicolumn{2}{|c|}{ Year } \\
\hline & Prog. & Est. & Prog. & Rev. Prog. & \multicolumn{4}{|c|}{ Revised Program } & Prog. & Rev. Prog. \\
\hline Net borrowing requirement $1 /$ & 802.6 & 776.1 & $1,528.9$ & $1,507.1$ & 586.1 & 125.8 & 0.7 & 17.3 & 668.9 & 729.9 \\
\hline \multicolumn{11}{|l|}{ Redemptions } \\
\hline In Hungarian forints & $1,555.4$ & $1,414.1$ & $5,914.3$ & $5,773.0$ & $1,115.1$ & $1,709.2$ & $1,830.2$ & $1,516.2$ & $7,148.1$ & $6,170.6$ \\
\hline In foreign currency (euro) & 5.3 & 8.4 & 161.0 & 164.1 & 159.4 & 117.3 & 9.0 & 6.3 & 302.6 & 292.1 \\
\hline Gross borrowing requirement & $2,363.2$ & $2,198.6$ & $7,604.2$ & $7,444.2$ & $1,860.7$ & $1,952.3$ & $1,839.8$ & $1,539.8$ & $8,119.6$ & $7,192.6$ \\
\hline \multicolumn{11}{|l|}{ Gross issuance 2/ } \\
\hline In Hungarian forints & $1,170.5$ & $1,066.9$ & $5,818.8$ & $5,715.2$ & 955.9 & $1,552.5$ & $1,747.2$ & $1,598.6$ & $6,727.3$ & $5,854.2$ \\
\hline In foreign currency $3 /$ & 560.0 & 524.8 & $1,069.6$ & $1,034.4$ & 580.0 & 580.0 & 0.0 & 435.0 & $1,861.6$ & $1,595.0$ \\
\hline Drawing on deposits with banking system & 632.7 & 606.9 & 715.8 & 694.5 & 324.8 & -180.2 & 92.6 & -493.8 & -469.3 & -256.6 \\
\hline
\end{tabular}

Sources: Hungarian authorities; and IMF staff estimates.

$1 /$ Overall budget balance of the central government system (cash basis) and costs of banking sector rescue package.

2/ No issuance in foreign currency, no net domestic currency issuance, rollover of maturing debt of 75 percent (08Q4 and 09Q1), 85 percent in 08Q2, 95 percent in

09Q3 and 105 percent in 09Q4.

$3 /$ Includes identified multilateral assistance from the EU and the World Bank. 
Table 8. Hungary: Financial Soundness Indicators for the Banking Sector, 2005-08 (In percent unless otherwise indicated, end of period)

\begin{tabular}{|c|c|c|c|c|}
\hline & 2005 & 2006 & 2007 & $20081 /$ \\
\hline \multicolumn{5}{|l|}{ Capital adequacy } \\
\hline Regulatory capital to risk-weighted assets & 11.6 & 11.0 & 10.4 & 11.1 \\
\hline Capital (net worth) to assets & 8.2 & 8.3 & 8.2 & 8.0 \\
\hline \multicolumn{5}{|l|}{ Asset composition and quality } \\
\hline Annual growth of bank loans & 19.8 & 18.4 & 22.1 & 21.0 \\
\hline \multicolumn{5}{|l|}{ Sectoral distribution of bank loans (in percent of total) } \\
\hline Corporates & 45.7 & 43.2 & 39.8 & 35.3 \\
\hline of which: in foreign currency & 21.8 & 20.3 & 20.9 & 21.3 \\
\hline Households & 29.2 & 31.5 & 32.7 & 36.0 \\
\hline of which: in foreign currency & 9.5 & 14.8 & 19.3 & 25.4 \\
\hline Other loans & 25.0 & 25.3 & 27.5 & 28.7 \\
\hline of which: in foreign currency & 18.8 & 19.1 & 22.5 & 25.0 \\
\hline Financial institutions & 12.3 & 11.3 & 10.7 & 9.5 \\
\hline Central government & 0.6 & 0.5 & 0.5 & 0.2 \\
\hline Nonresidents & 5.1 & 6.2 & 9.1 & 12.2 \\
\hline Other & 7.0 & 7.2 & 7.2 & 6.8 \\
\hline \multicolumn{5}{|l|}{ Denomination of FX loans to corporates } \\
\hline EUR & 74.8 & 70.7 & 67.8 & 67.1 \\
\hline USD & 5.7 & 4.7 & 5.1 & 4.2 \\
\hline $\mathrm{CHF}$ & 19.3 & 24.6 & 26.7 & 28.5 \\
\hline Other & 0.2 & 0.0 & 0.4 & 0.2 \\
\hline NPLs to gross loans 2/ & 2.5 & 2.5 & 2.5 & 2.9 \\
\hline Provisions to NPLs & 54.4 & 53.9 & 58.1 & 80.3 \\
\hline NPLs net of provisions to capital & 9.0 & 9.2 & 8.4 & 3.7 \\
\hline \multicolumn{5}{|l|}{ Earnings and profitability } \\
\hline ROA (after tax) & 2.0 & 1.8 & 1.4 & 1.5 \\
\hline ROE (after tax) & 24.7 & 24.0 & 18.1 & 17.7 \\
\hline Net interest income to gross income & 64.4 & 64.7 & 61.3 & 57.9 \\
\hline Noninterest expenses to gross income & 48.6 & 48.7 & 50.2 & 50.6 \\
\hline Personnel expenses to noninterest expenses & 47.2 & 48.3 & 48.9 & 49.0 \\
\hline Trading and fee income to total income & 33.8 & 32.3 & 36.1 & 29.3 \\
\hline Spread between loan and deposit rates & 3.7 & 3.5 & 3.2 & 2.5 \\
\hline \multicolumn{5}{|l|}{ Liquidity } \\
\hline Liquid assets to total assets & 21.0 & 20.0 & 16.4 & 15.5 \\
\hline Liquid assets to short term liabilities & 35.7 & 36.8 & 30.5 & 31.4 \\
\hline Loans to deposits & 107.7 & 109.9 & 121.6 & 125.0 \\
\hline $\begin{array}{l}\text { FX liabilities(own capital is excluded) to total liabilities(own } \\
\text { capital is excluded) }\end{array}$ & 34.4 & 39.3 & 42.4 & 45.6 \\
\hline \multicolumn{5}{|l|}{ Sensitivity to market risk } \\
\hline Net open position in FX to capital & 3.5 & 7.2 & 6.0 & 17.0 \\
\hline
\end{tabular}

Source: Magyar Nemzeti Bank.

1/ Preliminary.

2/ NPLs are defined as loans past due more than 90 days. 
Table 9. Hungary: Program Financing, 2008-09

(In millions of euros)

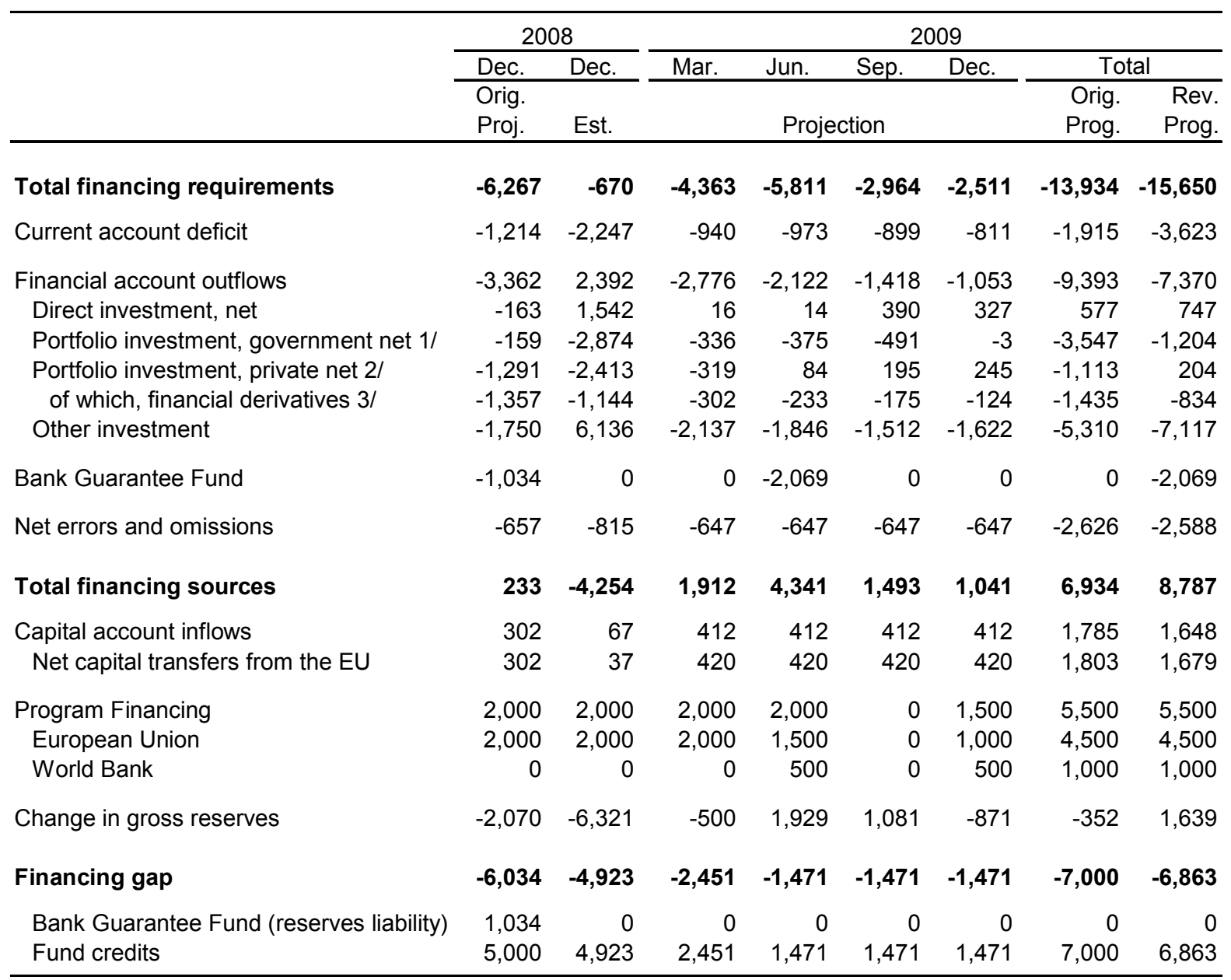

Sources: Hungarian authorities; and IMF staff projections.

1/ Financing difficulties are expected to persist through 2009, with no FX issuance.

2/ Banks with foreign parent banks are expected to roll over 80 percent of short-term debt, and others 70 percent. As a result, short-term financing for banks will be negative in 2009 (following years of large build-up of debt).

3/ 80 percent of FX swaps are expected to be rolled over, recovering to 90 percent in second half of 2009 . 
Table 10. Hungary: Schedule of Reviews and Purchases

\begin{tabular}{lrcl}
\hline & \multicolumn{2}{c}{ Amount of Purchase } & \\
\cline { 2 - 3 } \multicolumn{1}{c}{ Date } & Millions of SDRs & Percent of Quota & Conditions \\
\hline November 6, 2008 & $4,215.0$ & 405.9 & Approval of arrangement \\
March 25, 2009 & $2,107.5$ & 203.0 & First review and end-December 2008 performance criteria \\
May 15, 2009 & $1,264.5$ & 121.8 & Second review and end-March 2009 performance criteria \\
August 15, 2009 & $1,264.5$ & 121.8 & Third review and end-June 2009 performance criteria \\
November 15, 2009 & $1,264.5$ & 121.8 & Fourth review and end-September 2009 performance criteria \\
February 15, 2010 & 421.5 & 40.6 & Fifth review and end-December 2009 performance criteria \\
Total & $\mathbf{1 0 , 5 3 7 . 5}$ & $\mathbf{1 0 1 4 . 8}$ & \\
\hline
\end{tabular}

Source: IMF staff estimates. 
Table 11. Hungary. Indicators of Fund Credit, 2008-15 (In millions of SDR)

\begin{tabular}{|c|c|c|c|c|c|c|c|c|}
\hline & 2008 & 2009 & 2010 & 2011 & 2012 & 2013 & 2014 & 2015 \\
\hline \multicolumn{9}{|l|}{ Existing and prospective Fund credit } \\
\hline Disbursement & 4,215 & 5,901 & 422 & - & - & - & - & - \\
\hline Stock 1/ & 4,215 & 10,116 & 10,538 & 10,538 & 7,166 & 1,949 & 53 & - \\
\hline Obligations 2/ & 21 & 224 & 322 & 326 & 3,666 & 5,362 & 1,916 & 53 \\
\hline Repurchase & - & - & - & - & 3,372 & 5,216 & 1,897 & 53 \\
\hline Charges & 21 & 224 & 322 & 326 & 294 & 146 & 19 & 0 \\
\hline \multicolumn{9}{|l|}{ Stock of existing and prospective Fund credit } \\
\hline In percent of quota & 405.9 & 974.2 & 1014.8 & 1014.8 & 690.1 & 187.7 & 5.1 & - \\
\hline In percent of GDP & 4.3 & 12.3 & 12.0 & 11.3 & 7.0 & 1.8 & 0.0 & - \\
\hline In percent of exports of goods and services & 5.3 & 14.0 & 13.6 & 12.9 & 8.3 & 2.1 & 0.1 & - \\
\hline In percent of gross reserves & 18.9 & 50.5 & 57.1 & 54.1 & 31.1 & 7.1 & 0.2 & - \\
\hline \multicolumn{9}{|c|}{ Obligations to the Fund from existing and prospective Fund arrangements } \\
\hline In percent of quota & 2.0 & 21.6 & 31.0 & 31.4 & 353.1 & 516.4 & 184.5 & 5.1 \\
\hline In percent of GDP & 0.0 & 0.3 & 0.4 & 0.3 & 3.6 & 4.8 & 1.5 & 0.0 \\
\hline In percent of exports of goods and services & 0.0 & 0.3 & 0.4 & 0.4 & 4.2 & 5.9 & 2.0 & 0.1 \\
\hline In percent of gross reserves & 0.1 & 1.1 & 1.7 & 1.7 & 15.9 & 19.5 & 6.2 & 0.1 \\
\hline
\end{tabular}

Source: IMF staff estimates.

$1 /$ End of period.

2/ Repayment schedule based on repurchase obligations. 
Appendix Table 1. Hungary: Public Sector Debt Sustainability Framework, 2004-14

(In percent of GDP, unless otherwise indicated)

\begin{tabular}{|c|c|c|c|c|c|c|c|c|c|c|c|c|}
\hline & \multicolumn{5}{|c|}{ Actual } & \multicolumn{6}{|c|}{ Projections } & \multirow{3}{*}{$\begin{array}{c}\text { Debt-stabilizing } \\
\text { primary } \\
\text { balance } 10 /\end{array}$} \\
\hline & 2004 & 2005 & 2006 & 2007 & 2008 & 2009 & 2010 & 2011 & 2012 & 2013 & 2014 & \\
\hline \multirow{3}{*}{$\begin{array}{l}\text { Baseline: Public sector debt } 1 / \\
\text { o/w foreign-currency denominated }\end{array}$} & & & & & & & & & & & & \\
\hline & 59.4 & 61.8 & 65.6 & 65.9 & 72.2 & 75.9 & 72.2 & 69.0 & 66.2 & 62.4 & 59.0 & -0.3 \\
\hline & 15.3 & 17.4 & 18.5 & 18.5 & 26.3 & 37.8 & 38.6 & 37.6 & 30.8 & 22.8 & 19.1 & \\
\hline Change in public sector debt & 1.4 & 2.4 & 3.8 & 0.3 & 6.3 & 3.7 & -3.7 & -3.2 & -2.8 & -3.8 & -3.4 & \\
\hline Identified debt-creating flows $(4+7+12)$ & 0.6 & 0.3 & 6.6 & -1.1 & 0.6 & 3.0 & 0.7 & -1.5 & -2.4 & -3.7 & -4.5 & \\
\hline Primary deficit & 2.0 & 3.7 & 5.4 & 0.9 & -0.7 & -1.5 & -2.2 & -2.4 & -2.2 & -3.2 & -4.1 & \\
\hline Revenue and grants & 42.6 & 42.3 & 42.6 & 44.9 & 45.9 & 46.5 & 48.9 & 48.7 & 46.1 & 46.1 & 46.1 & \\
\hline Primary (noninterest) expenditure & 44.6 & 46.0 & 48.0 & 45.8 & 45.1 & 45.0 & 46.8 & 46.3 & 43.9 & 42.9 & 42.0 & \\
\hline Automatic debt dynamics $2 /$ & -0.6 & -1.4 & 2.4 & -2.0 & -1.0 & 4.5 & 2.9 & 0.9 & -0.2 & -0.5 & -0.4 & \\
\hline Contribution from interest rate/growth differential $3 /$ & -0.6 & 0.6 & -0.7 & -0.2 & 0.9 & 4.5 & 2.9 & 0.9 & -0.2 & -0.5 & -0.4 & \\
\hline Of which contribution from real interest rate & 2.0 & 2.9 & 1.6 & 0.5 & 1.2 & 2.1 & 2.6 & 2.6 & 2.2 & 2.2 & 2.2 & \\
\hline Of which contribution from real GDP growth & -2.6 & -2.3 & -2.3 & -0.7 & -0.4 & 2.4 & 0.3 & -1.7 & -2.5 & -2.8 & -2.6 & \\
\hline Contribution from exchange rate depreciation $4 /$ & 0.0 & -2.0 & 3.1 & -1.9 & -1.8 & & & $\ldots$ & & & & \\
\hline Other identified debt-creating flows & -0.8 & -2.0 & -1.2 & 0.0 & 2.2 & 0.0 & 0.0 & 0.0 & 0.0 & 0.0 & 0.0 & \\
\hline Privatization receipts (negative) & -0.8 & -2.0 & -1.2 & 0.0 & 0.0 & 0.0 & 0.0 & 0.0 & 0.0 & 0.0 & 0.0 & \\
\hline Recognition of implicit or contingent liabilities & 0.0 & 0.0 & 0.0 & 0.0 & 0.0 & 0.0 & 0.0 & 0.0 & 0.0 & 0.0 & 0.0 & \\
\hline Other (specify, e.g. bank recapitalization) & 0.0 & 0.0 & 0.0 & 0.0 & 2.2 & 0.0 & 0.0 & 0.0 & 0.0 & 0.0 & 0.0 & \\
\hline Residual, including asset changes (2-3) 5/ & 0.8 & 2.1 & -2.8 & 1.4 & 5.7 & 0.7 & -4.4 & -1.7 & -0.3 & -0.1 & 1.1 & \\
\hline Public sector debt-to-revenue ratio 1 / & 139.5 & 146.3 & 154.1 & 146.9 & 157.4 & 163.3 & 147.6 & 141.8 & 143.6 & 135.3 & 127.9 & \\
\hline Gross financing need 6 / & 23.2 & 24.6 & 24.3 & 18.7 & 24.1 & 19.7 & 18.6 & 14.8 & 14.1 & 12.2 & 10.7 & \\
\hline in billions of U.S. dollars & 23.7 & 27.2 & 27.5 & 25.9 & 37.7 & 24.8 & 25.1 & 21.3 & 22.3 & 20.9 & 19.9 & \\
\hline Scenario with key variables at their historical averages $7 /$ & & & & & & 75.9 & 71.8 & 70.3 & 70.3 & 70.4 & 71.7 & -0.9 \\
\hline Scenario with no policy change (constant primary balance) in 2009-2014 & & & & & & 75.9 & 78.9 & 75.6 & 72.4 & 69.8 & 68.7 & -0.5 \\
\hline \multicolumn{13}{|l|}{ Key Macroeconomic and Fiscal Assumptions Underlying Baseline } \\
\hline Real GDP growth (in percent) & 4.8 & 4.0 & 4.0 & 1.1 & 0.6 & -3.3 & -0.4 & 2.5 & 3.8 & 4.5 & 4.5 & \\
\hline Average nominal interest rate on public debt (in percent) 9/ & 8.3 & 7.4 & 6.9 & 6.6 & 6.4 & 6.0 & 6.5 & 6.9 & 6.6 & 6.8 & 7.0 & \\
\hline Average real interest rate (nominal rate minus change in GDP deflator, in percent) & 3.9 & 5.2 & 3.0 & 0.9 & 2.0 & 2.7 & 3.5 & 3.9 & 3.6 & 3.8 & 4.0 & \\
\hline Nominal appreciation (increase in US dollar value of local currency, in percent) & 0.0 & 15.3 & -15.6 & 11.5 & 11.0 & & & & & & & \\
\hline Inflation rate (GDP deflator, in percent) & 4.4 & 2.2 & 3.9 & 5.7 & 4.4 & 3.2 & 3.0 & 3.0 & 3.0 & 3.0 & 3.0 & \\
\hline Growth of real primary spending (deflated by GDP deflator, in percent) & 3.7 & 7.2 & 8.6 & -3.5 & -0.9 & -3.6 & 3.4 & 1.5 & -1.5 & 2.1 & 2.2 & \\
\hline Primary deficit & 2.0 & 3.7 & 5.4 & 0.9 & -0.7 & -1.5 & -2.2 & -2.4 & -2.2 & -3.2 & -4.1 & \\
\hline
\end{tabular}

$1 /$ General government gross debt.

2/ Derived as $[(r-\pi(1+g)-g+\alpha \varepsilon(1+r)] /(1+g+\pi+g \pi))$ times previous period debt ratio, with $r=$ interest rate; $\pi=$ growth rate of GDP deflator; $g=$ real GDP growth rate; $\alpha=$ share of foreign-currency

denominated debt: and $\varepsilon=$ nominal exchange rate depreciation (measured by increase in local currency value of U.S. dollar).

$3 /$ The real interest rate contribution is derived from the denominator in footnote $2 /$ as $r-\pi(1+g)$ and the real growth contribution as $-g$.

$4 /$ The exchange rate contribution is derived from the numerator in footnote $2 /$ as $\alpha \varepsilon(1+r)$.

$5 /$ For projections, this line includes exchange rate changes.

6/ Defined as public sector deficit plus amortization of medium and long-term public sector debt, plus short-term debt at end of previous period.

7/ The key variables include real GDP growth; real interest rate; and primary balance in percent of GDP.

作

.

10/ Assumes that key variables (real GDP growth, real interest rate, and other identified debt-creating flows) remain at the level of the last projection year. 
Appendix Table 2. Hungary: External Debt Sustainability Framework, 2004-14

(In percent of GDP, unless otherwise indicated)

\begin{tabular}{|c|c|c|c|c|c|c|c|c|c|c|c|c|}
\hline & \multicolumn{5}{|c|}{ Actual } & \multicolumn{7}{|c|}{ Projections } \\
\hline & 2004 & 2005 & 2006 & 2007 & 2008 & 2009 & 2010 & 2011 & 2012 & 2013 & 2014 & $\overline{\text { Debt-stabilizing }}$ \\
\hline Baseline: External debt & 67.0 & 75.1 & 90.5 & 97.2 & 114.4 & 131.0 & 127.1 & 123.1 & 116.3 & 108.5 & 100.7 & $\begin{array}{c}\text { current account } 6 / \\
-6.5\end{array}$ \\
\hline Change in external debt & 12.5 & 8.1 & 15.4 & 6.7 & 17.2 & 16.7 & -3.9 & -4.0 & -6.8 & -7.8 & -7.8 & \\
\hline Identified external debt-creating flows $(4+8+9)$ & -5.2 & 2.4 & 9.2 & 4.5 & 7.7 & 12.9 & 6.0 & -1.3 & -4.4 & -5.5 & -3.8 & \\
\hline Current account deficit, excluding interest payments & 5.8 & 4.6 & 4.4 & 2.8 & 2.6 & -2.3 & -2.8 & -3.1 & -4.5 & -5.7 & -6.3 & \\
\hline Deficit in balance of goods and services & 2.7 & 1.2 & 0.9 & -1.4 & -1.4 & -4.9 & -5.4 & -5.7 & -6.5 & -7.3 & -7.8 & \\
\hline Exports & 65.0 & 67.7 & 76.7 & 79.9 & 80.5 & 88.2 & 88.8 & 87.1 & 84.6 & 82.4 & 77.0 & \\
\hline Imports & 67.7 & 68.9 & 77.6 & 78.6 & 79.1 & 83.3 & 83.4 & 81.4 & 78.1 & 75.0 & 69.1 & \\
\hline Net non-debt creating capital inflows (negative) & -5.4 & -0.6 & 4.1 & 7.0 & 4.5 & 4.5 & 2.0 & -1.4 & -2.5 & -2.2 & -0.5 & \\
\hline Automatic debt dynamics $1 /$ & -5.5 & -1.6 & 0.8 & -5.3 & 0.5 & 10.7 & 6.8 & 3.3 & 2.5 & 2.4 & 3.1 & \\
\hline Contribution from nominal interest rate & 2.6 & 2.9 & 3.2 & 3.7 & 5.2 & 6.3 & 6.2 & 6.3 & 6.8 & 7.2 & 7.3 & \\
\hline Contribution from real GDP growth & -4.3 & -2.4 & -3.0 & -0.9 & -0.5 & 4.4 & 0.6 & -3.0 & -4.3 & -4.8 & -4.3 & \\
\hline Contribution from price and exchange rate changes $2 /$ & -3.8 & -2.1 & 0.6 & -8.1 & -4.1 & $\ldots$ & $\ldots$ & $\ldots$ & $\ldots$ & $\ldots$ & $\ldots$ & \\
\hline Residual, incl. change in gross foreign assets (2-3) $3 /$ & 17.7 & 5.8 & 6.1 & 2.2 & 9.5 & 3.8 & -9.9 & -2.8 & -2.3 & -2.3 & -4.0 & \\
\hline External debt-to-exports ratio (in percent) & 103.1 & 111.0 & 118.0 & 121.6 & 142.0 & 148.6 & 143.1 & 141.2 & 137.5 & 131.7 & 130.9 & \\
\hline Gross external financing need (in billions of euros) $4 /$ & 23.6 & 28.4 & 32.4 & 30.9 & 40.8 & 54.3 & 44.8 & 43.6 & 48.3 & 54.7 & 55.1 & \\
\hline in percent of GDP & 28.6 & 32.0 & 36.0 & 30.5 & 38.4 & 59.0 & 45.8 & 41.8 & 42.6 & 44.5 & 39.2 & \\
\hline Scenario with key variables at their historical averages $5 /$ & & & & & & 131.0 & 125.9 & 124.8 & 124.8 & 123.3 & 125.3 & -7.2 \\
\hline Key Macroeconomic Assumptions Underlying Baseline & & & & & & & & & & & & \\
\hline Real GDP growth (in percent) & 9.2 & 3.9 & 4.0 & 1.1 & 0.6 & -3.3 & -0.4 & 2.5 & 3.8 & 4.5 & 4.5 & \\
\hline GDP deflator in euros (change in percent) & 6.6 & 3.7 & -2.5 & 11.2 & 4.5 & -10.6 & 6.7 & 4.1 & 4.9 & 3.7 & 9.6 & \\
\hline Nominal external interest rate (in percent) & 5.6 & 4.7 & 4.3 & 4.5 & 5.6 & 4.8 & 5.1 & 5.3 & 6.0 & 6.8 & 7.7 & \\
\hline Growth of exports (euro terms, in percent) & 20.2 & 12.2 & 15.0 & 17.1 & 6.0 & -5.4 & 7.0 & 4.7 & 5.7 & 5.6 & 7.0 & \\
\hline Growth of imports (euro terms, in percent) & 20.8 & 9.7 & 14.2 & 13.8 & 5.9 & -9.0 & 6.4 & 4.2 & 4.4 & 4.2 & 5.5 & \\
\hline Current account balance, excluding interest payments & -5.8 & -4.6 & -4.4 & -2.8 & -2.6 & 2.3 & 2.8 & 3.1 & 4.5 & 5.7 & 6.3 & \\
\hline Net non-debt creating capital inflows & 5.4 & 0.6 & -4.1 & -7.0 & -4.5 & -4.5 & -2.0 & 1.4 & 2.5 & 2.2 & 0.5 & \\
\hline
\end{tabular}

1/ Derived as $[r-g-\rho(1+g)+\varepsilon \alpha(1+r)] /(1+g+\rho+g \rho)$ times previous period debt stock, with $r=$ nominal effective interest rate on external debt; $\rho=$ change in domestic GDP deflator in euro terms, $g=$ real GDP growth rate, $\varepsilon=$ nominal appreciation (increase in dollar value of domestic currency), and $\alpha=$ share of domestic-currency denominated debt in total external debt.

$2 /$ The contribution from price and exchange rate changes is defined as $[-\rho(1+g)+\varepsilon \alpha(1+r)] /(1+g+\rho+g \rho)$ times previous period debt stock. $\rho$ increases with an appreciating domestic currency $(\varepsilon>0)$ and rising inflation (based on GDP deflator).

$3 /$ For projection, line includes the impact of price and exchange rate changes.

4/ Defined as current account deficit, plus amortization on medium- and long-term debt, plus short-term debt at end of previous period.

5/ The key variables include real GDP growth; nominal interest rate; dollar deflator growth; and both non-interest current account and non-debt inflows in percent of GDP.

6/ Long-run, constant balance that stabilizes the debt ratio assuming that key variables (real GDP growth, nominal interest rate, dollar deflator growth, and non-debt inflows in percent of GDP) remain at their levels of the last projection year. 
Appendix Figure 1. Hungary: Public Debt Sustainability: Bound Tests 1/ (Public debt in percent of GDP)
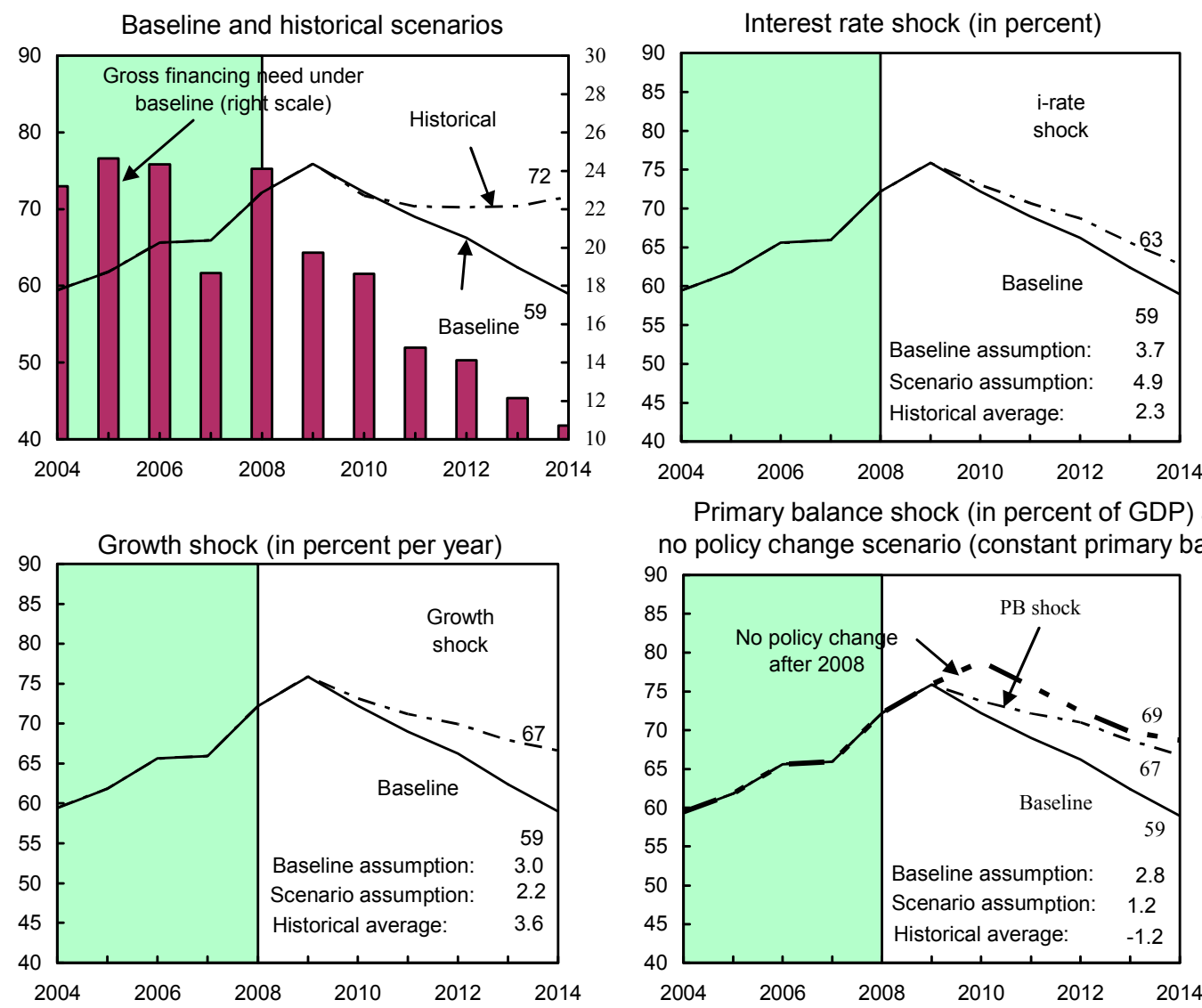

Primary balance shock (in percent of GDP) and no policy change scenario (constant primary balance)
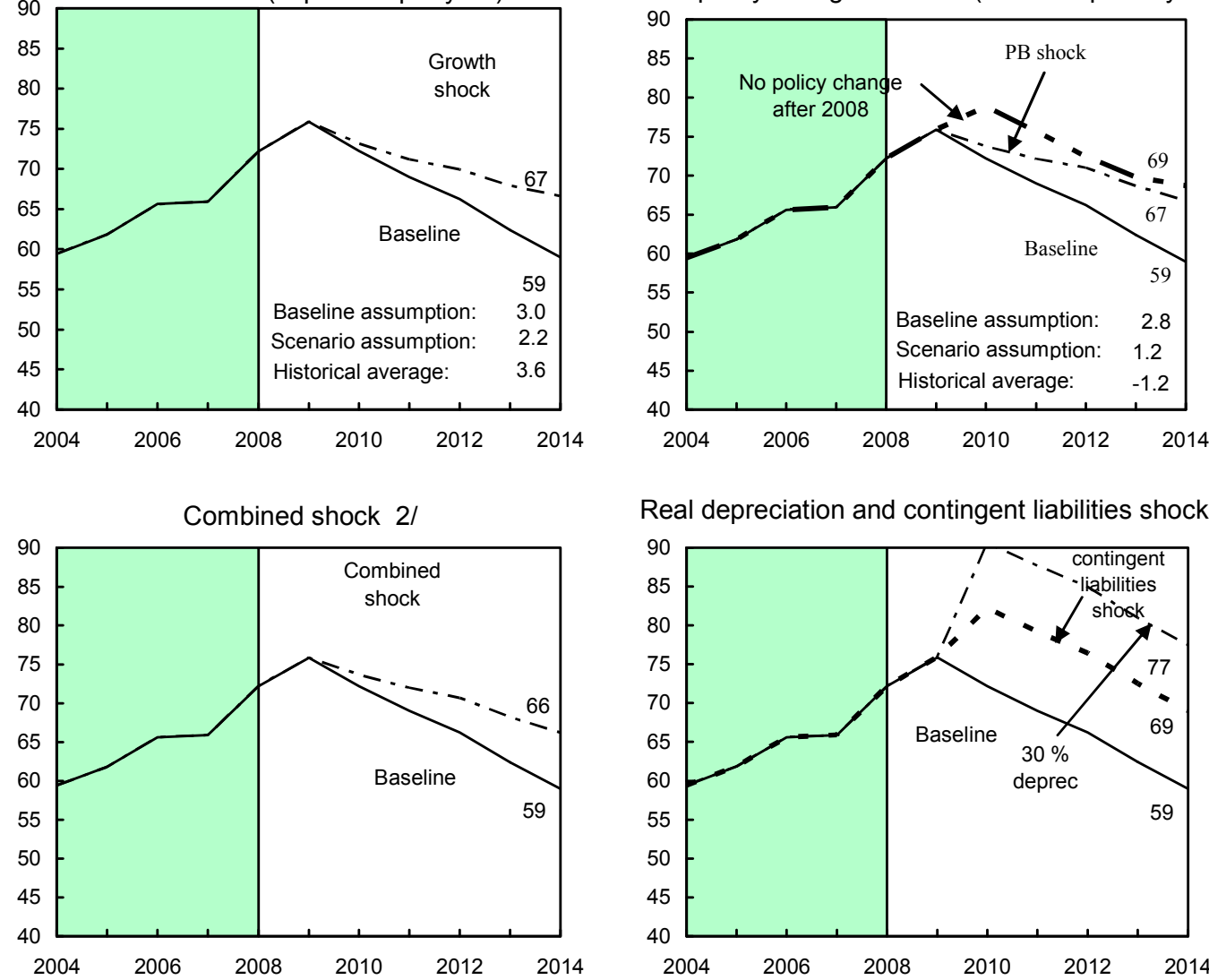

Real depreciation and contingent liabilities shocks 3/

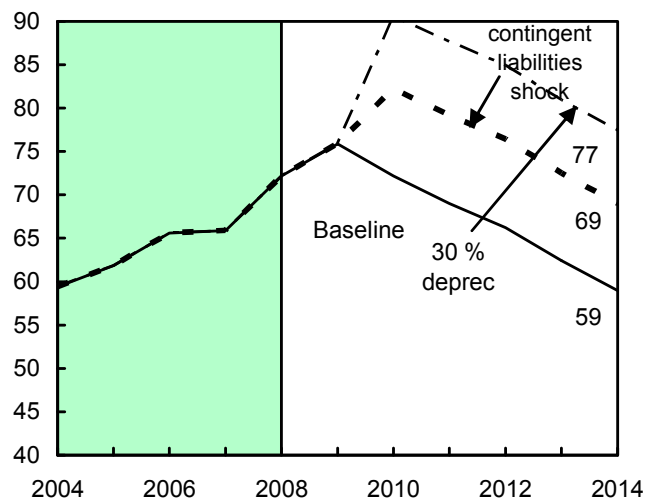

Sources: International Monetary Fund, country desk data, and staff estimates.

1/ Shaded areas represent actual data. Individual shocks are permanent one-half standard deviation shocks. Figures in the boxes represent average projections for the respective variables in the baseline and scenario being presented. Ten-year historical average for the variable is also shown.

2/ Permanent $1 / 4$ standard deviation shocks applied to real interest rate, growth rate, and primary balance.

$3 /$ One-time real depreciation of 30 percent and 10 percent of GDP shock to contingent liabilities occur in 2009, with real depreciation defined as nominal depreciation (measured by percentage fall in dollar value of local currency) minus domestic inflation (based on GDP deflator). 
Appendix Figure 2. Hungary: External Debt Sustainability: Bound Tests 1/ (External debt in percent of GDP)
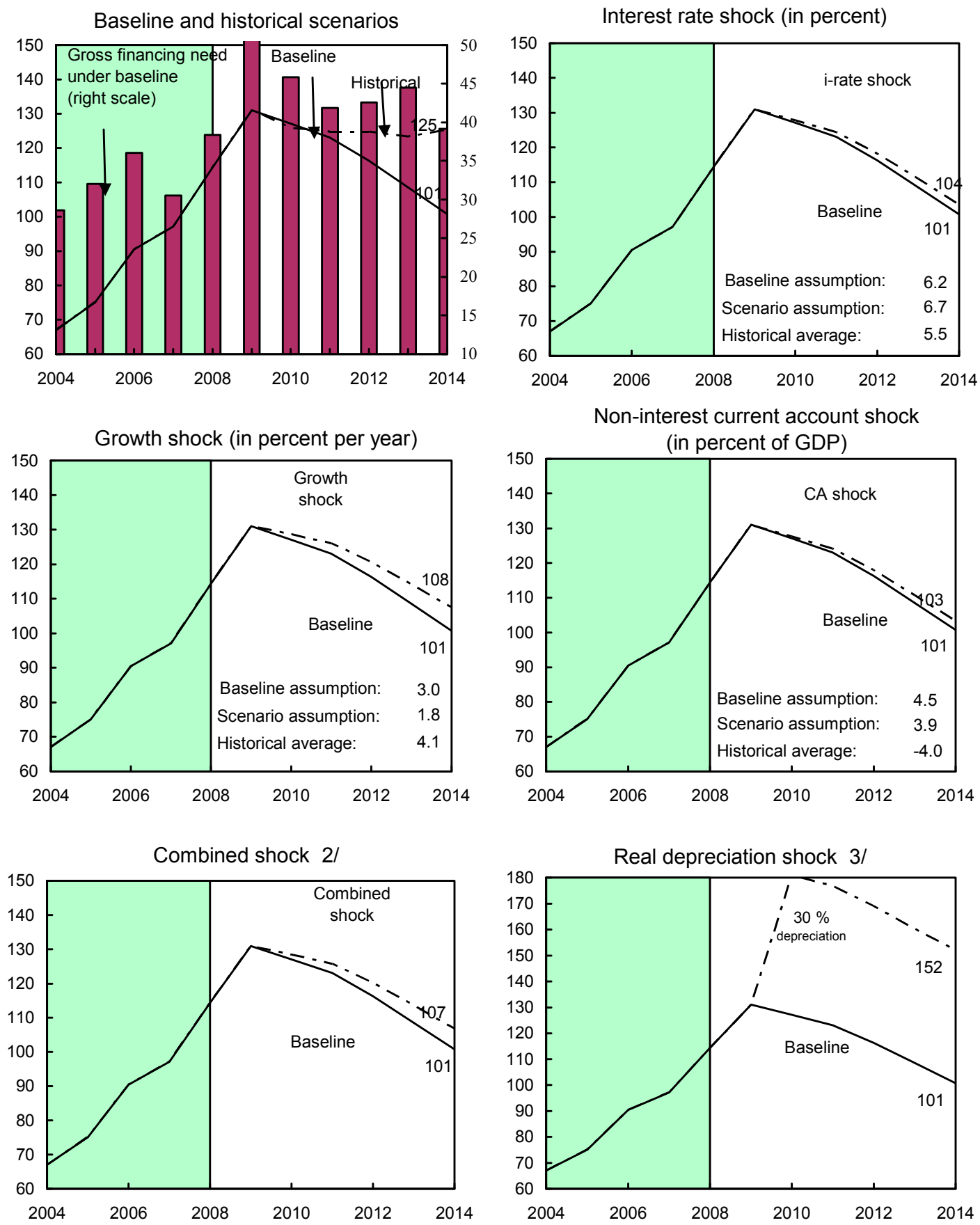

Sources: International Monetary Fund, Country desk data, and staff estimates.

1/ Shaded areas represent actual data. Individual shocks are permanent one-half standard deviation shocks. Figures in the boxes represent average projections for the respective variables in the baseline and scenario being presented. Ten-year historical average for the variable is also shown.

2/ Permanent 1/4 standard deviation shocks applied to real interest rate, growth rate, and current account balance.

3/ One-time real depreciation of 30 percent occurs in 2009. 


\section{ATtACHMENT I. HungARY: LetTER OF INTENT}

Mr. Dominique Strauss-Kahn

Managing Director

International Monetary Fund

Washington, DC, 20431

U.S.A.
Budapest, March 11, 2009

Dear Mr. Strauss-Kahn:

1. Since the announcement of the IMF-supported program in November 2008, financial strains in Hungary have moderated, but the external environment has deteriorated. The IMF's January 2009 World Economic Outlook Update projects a much more severe contraction in advanced economies in 2009 than foreseen only a few months ago. Weak external demand and tight global financing conditions will be significant drags on the Hungarian economy in 2009.

2. In spite of the difficult external environment, policy implementation under our economic program has been strong (Tables 1 and 2).

- Quantitative performance criteria and inflation consultation mechanism. All quantitative performance criteria for end-December 2008 and the continuous performance criterion on non-accumulation of external arrears were met, as well as the end-December 2008 indicative target on central government debt. CPI inflation in December 2008 was 3.5 percent, lower than the inner band but within the outer band under the program. Inflation fell faster than expected chiefly because of the sharp drop in global commodity prices.

- $\quad$ Structural performance criterion and benchmarks. The Government submitted to Parliament on November 10, 2008 the draft support package for domestic banks and requested the initiation of an extraordinary procedure for early passage, meeting the related performance criterion. The structural benchmarks on passage of the fiscal responsibility law and on submission to Parliament of a law strengthening the remedial action and emergency powers of the Hungarian Financial Supervisory Authority (HFSA) were also met.

3. In light of this performance and our continued commitment to the program, we request completion of the First Review under the Stand-By arrangement. Given the sharp fall in inflation, we request a lowering of the inflation consultation bands for end-March 2009. Since inflation is currently within our medium-term target range, we propose resetting the inflation consultation clause to be consistent with our inflation-targeting framework. We also 
request a modification to the performance criteria on Net International Reserves (NIR) at end-March 2009 to save the overperformance at end-December 2008, which will further reduce Hungary's vulnerability to a deterioration in external financing conditions.

Performance criteria and benchmarks through end-June 2009 are set out in Tables 2 and 3, as well as in the attached Technical Memorandum of Understanding. The third review of the program will take place after August 14, 2009.

4. We believe that the policies set forth in the letter of November 4, 2008 and in this letter are adequate to achieve the objectives of our economic program, but the Government stands ready to take additional measures as appropriate to ensure achievement of its objectives. As is standard under all IMF arrangements, we will consult with the IMF before modifying measures contained in this letter, or adopting new measures that would deviate from the goals of the program, and provide the IMF with the necessary information for program monitoring.

\section{Macroeconomic Framework for 2009}

5. Preliminary estimates indicate that the economy grew by only 0.6 percent in 2008 , owing to a severe slowdown in the second half of the year. The decline in growth was broadbased, with a simultaneous slowing of consumption, investment, exports, and imports. Going forward, we expect domestic demand to decline further in 2009, with tighter credit markets affecting consumption and investment, while exports will remain subdued. As a result, we now anticipate a contraction of about 3.0-3.3 percent for the year, while recognizing the unusually large uncertainties that surround the outlook.

6. CPI inflation has fallen more rapidly than expected, from 6.7 percent in June 2008 to 3.1 percent by January 2009, reflecting the drop in global food and fuel prices. Looking forward, the opening up of the output gap is expected to keep inflation low, with average inflation in 2009 projected at 3.7-3.9 percent. This projection is contingent on developments in energy markets, exchange rate movements, and the response of inflation to tax measures.

7. The current account deficit for 2008 is estimated at 7.9 percent of GDP, higher than originally programmed, largely reflecting a worse income balance. Going forward, exports in 2009 are likely to contract by more than originally anticipated, reflecting weaker growth in partner countries. We now expect the current account deficit to narrow by 4 percentage points of GDP in 2009, about the same as in the original program.

8. External financing has so far held up better than expected, but the continued stress in global financial markets points to the need for caution in projecting Hungary's external financing need. Funding of parent banks to their Hungarian subsidiaries has remained stable, but external funding of corporations has declined since October 2008, as has the stock of government bonds held by non-residents. The higher than programmed increase in international reserves in the fourth quarter of 2008 can help to mitigate unexpected outflows going forward. However, Hungary's high debt rollover needs combined with the fragility of 
global financial conditions suggest an external financing need broadly in line with original program projections, which will be covered by continued financial support from the IMF, the European Union (EU), and the World Bank.

\section{Fiscal Policy and Structural Fiscal Reforms}

9. Reducing the government's financing needs is an essential objective of the program, contributing to anchor market expectations, stabilize financial conditions and lower interest rates. Acutely aware of the importance to further reduce fiscal vulnerabilities by putting the public debt-to-GDP ratio firmly on a declining path, we will continue to cut public expenditure over the medium term, therefore creating the fiscal space needed to ease the excessive tax burden on labor and bolster potential growth.

10. Strict expenditure control allowed the primary balance of the central government system to remain above the programmed floor at end December 2008 (quarterly performance criterion). In particular, we froze all budgetary reserves, except for the allocation of an earmarked reserve to cover operating losses in public transport. On the revenue side, performance remained strong despite emerging weakness in corporate income tax (CIT) and, to a lesser extent, value added tax (VAT) outturns. As a result, the deficit for the central government system for 2008 is estimated at 3.3 percent of GDP (both on accrual and cash basis), slightly below our November 2008 estimate of 3.4 percent.

11. Fiscal credibility was also supported by institutional reforms. In November 2008, Parliament adopted the fiscal responsibility law subjecting budget preparation to fiscal rules aimed at restoring public debt sustainability and containing the growth of public expenditures (structural benchmark). The law enhances transparency and accountability by establishing an independent Fiscal Council whose tasks include: (i) preparing macroeconomic and fiscal projections, (ii) estimating the budgetary impact of draft legislations, (iii) assessing compliance with the fiscal rules, and (iv) making recommendations on methodological matters when needed. On February 16, 2009, three independent and reputable fiscal experts were approved by Parliament to serve in the Council for a nine-year term. Adequate financial and human resources are necessary for the Council and its Secretariat to fulfill its tasks, and by end-March 2009, we will appropriate HUF 1-2 billion from the general reserve to fund the Council.

12. Government revenue in 2009 will be hurt by weaker nominal GDP growth, with a shortfall of about HUF 300 billion now anticipated with respect to the 2009 budget. Raising taxes is not an option given Hungary's already high tax burden, while fully offsetting the revenue shortfall with expenditure cuts would imply excessively procyclical fiscal policy. Therefore, we have identified spending cuts whose net impact is estimated at HUF 190 billion this year and revised the target for the general government deficit to 2.9 percent of GDP, compared to an original target of 2.6 percent. The implied structural fiscal adjustment is higher than originally envisaged. 
13. The additional fiscal adjustment in 2009 consists mostly of expenditure cuts, leaving the contingency reserve of 0.3 percent of GDP unaffected. Measures include: (i) cuts in operating budgets of line ministries and health care institutions, (ii) reductions in housing subsidies along with tighter eligibility criteria, (iii) a cutback in the national top-up payment on farm subsidies while allowing them to grow somewhat in real terms; (iv) a stricter enforcement of eligibility criteria for disability pensions; (v) and an offset of the programmed decline in fuel prices by a reduction in subsidies. Also, the fiscal balance will be helped by the sale of pollution rights under the terms of the Kyoto Protocol.

14. We have consequently adjusted the targeted path for the primary cash balance of the central government system (quarterly performance criterion). We will continue to monitor closely budgetary outturns and consult with IMF staff on corrective actions and on eventual adjustments to the targets should revenue performance be weaker-than-expected, or if public debt exceeds its indicative path by more than HUF 300 billion.

15. As the sharp global downturn will inevitably slow the pace of improvement in the headline budget balance, it is critical to anchor the credibility of our adjustment strategy in a comprehensive structural reform package aimed at reducing public spending on a permanent basis. While the short-term budgetary saving due to structural measures is low, it is expected to grow rapidly over time. Equally important is the fact that the reforms address key structural impediments to job creation, with expected beneficial effects on labor participation and, ultimately, the long-term financial sustainability of the welfare system, including pensions.

- Pension reforms. First, as of 2010, the "Swiss" indexation formula (which averages the inflation rate of the pensioners' consumer price index and net wage inflation, with equal weights) will only be applied if expected real GDP growth for the year exceeds 4 percent. The weight of the CPI will be increased to 60 percent if growth is expected to be in the 3 to 4 percent range, and to 80 percent in the 2 to 3 percent range. Full CPI indexation will apply if growth is expected to be below 2 percent. Second, to bolster incentives of employable individuals to take advantage of the rehabilitation scheme and rejoin the labor force, we will mandate a stricter enforcement of eligibility criteria for disability pensions both for new applicants and for existing beneficiaries (through triennial reviews of medical conditions and employability). Third, we will cancel increases of certain disability pensions originally planned for 2010, while increasing benefits for the poorest disabled. Fourth, the $13^{\text {th }}$ month pension will be abolished for new beneficiaries. Existing recipients will have their $13^{\text {th }}$ monthly installment - already capped at HUF 80,000 under the programincorporated into the new regular 12-months payment schedule. Fifth, starting in 2016 , the statutory retirement age will be increased by four months every year until it reaches 65 in 2025. We will submit to Parliament all legislative changes required to implement the above measures by end-March 2009 (structural performance criterion), 
with passage by parliament expected by June 2009, in time for implementation as of January 1, 2010.

- Improving the targeting of social transfers. As of September 2009, family allowances will be added to the income tax base, while remaining exempt from income taxation. As a result, higher income earners will pay more income tax. Starting in 2010, we will preserve the nominal value of all social transfers for two years, and we will mandate community work in exchange for social benefits in the context of our "pathway to work" initiative. We will reform the cash support system for the first years of parenthood by taking into account the length of employment of the eligible person in determining the length of the salary-related child allowance.

- $\quad$ Reducing inefficient subsidies. By end-March 2009, the interest subsidy on forintdenominated mortgages will be cut in half; eligibility conditions for the housing subsidy will be tightened; and the subsidy associated with the housing savings plan will be eliminated if the accumulated saving is not used to purchase residential real estate. As of June 2009, we will reduce energy subsidies so as to offset the predicted reduction in prices; the Government decree on this was modified in February 2009. Accordingly, we will freeze HUF 20 billion of the corresponding budget appropriation, and implement further subsidy reductions if necessary. Eligibility criteria for free catering in public schools will be tightened. In 2010, energy subsidy rates and eligibility criteria will be adjusted further so as to cut the budget appropriation to HUF 40 billion or less.

- $\quad$ Efficiency gains. We are committed to increase efficiency in the delivery of public goods and services. In particular, we will (i) take steps to eliminate redundant transfers and subsidies provided by different government levels, (ii) encourage local government to seek economies of scale by cutting central government transfers (in the 2010 budget), and (iii) propose a reduction in the size of local councils (a decision that would require a supermajority, and for which consultations are currently under way).

16. To further encourage job creation and strengthen potential growth, it is imperative to reduce the tax wedge on labor. The state of our public finances nevertheless requires such reform to be revenue-neutral until we reach a broadly balanced budget position on a sustainable basis. This implies that labor tax cuts envisaged under the program will be fully offset by higher consumption and wealth taxes.

- $\quad$ Main tax cuts. As of July 1, 2009, employers' social security contributions will be reduced by 5 percentage points for all workers, initially for the part of their income up to twice the minimum wage, and in 2010 for their whole income. Personal income tax payments will be reduced through an increase in tax brackets. The individual 
solidarity tax of 4 percent as well as the corporate solidarity tax will be eliminated as of 2010 .

- $\quad$ The main offsetting measures consist of higher consumption taxes and basebroadening measures. The normal VAT rate will be raised by 3 percentage points (effective July 1, 2009), and excise duties on alcohol, tobacco and fuel will be increased by 5 percent on average. Starting in 2010, the corporate income tax base will be broadened, and the normal rate set at 19 percent. Similarly, the personal income tax base will include all fringe benefits and universal social benefits, while deductions (except for the family allowance and the allowance for long term saving) will be abolished. These measures are currently being discussed with various social partners, and will be submitted to parliament thereafter.

\section{Financial Sector Policies}

17. The liquidity situation of the banking sector has improved. Western European parent banks increased funding of their Hungarian subsidiaries during the turbulence in October and November of 2008, and have since maintained their exposure. Moreover, banks have attracted more deposits from households. The additional funds have been used to acquire liquid assets, notably government bonds and central bank bills. As a result, when the forint came again under pressure starting in January 2009, the banking system withstood these strains without noticeable liquidity strains so far. The counterpart to the improved liquidity position has been a slowdown in lending to the private sector, especially corporations. The banking system's capital position remains well above capital adequacy requirements, but profits - which have already fallen in the fourth quarter of 2008 - will be under increasing pressure in 2009 as a result of increased funding costs and provisions for non-performing loans.

18. We have made progress in implementing the Financial Stability Act that was approved by Parliament in December 2008. The Act includes a Capital Enhancement Scheme available until end-March 2009 and a Bank Borrowing Guarantee Scheme, with guarantees to be issued until end-2009. The European Commission has ruled that the Act complies with EU competition rules. However, bank interest has been limited so far. To preserve the continuity of the safety net for banks, and as part of the regular review of such measures requested by the Commission, we will review the Act and submit to before Parliament a set of technical amendments by March 31, 2009 (structural performance criterion). The amendments will include: (i) aligning the expiration date of the capital enhancement component with that of the guarantee component; (ii) specifying that the option granted to shareholders of a troubled bank to sell their share to the state should be exercised at a price reflecting the current and prospective financial conditions of the bank as determined by an independent third party jointly selected by the central bank (Magyar Nemzeti Bank, or MNB) and the HFSA; and (iii) clarifying in the Act that a mandatory capital increase pursuant to Article $8(1)$ (b) is linked to any of the three thresholds concerning a severe deterioration in the 
financial condition of the affected bank (Article 16). In addition, the government may lend in domestic or foreign currency directly to systemically-important banks to support the real economy. As part of the safeguards for such lending, we will establish a subcommittee of the Financial Stability Committee (which includes the Ministry of Finance, the central bank, and the HFSA) by end-March 2009 (structural performance criterion). The subcommittee will monitor the financial soundness and stress-resilience of any bank that receives any capital or funding support from the government. The sub-committee will be operational as long as there is any capital or funding support outstanding to banks and will consult with Fund staff on its work program (continuous structural benchmark).

19. We have taken steps to strengthen the remedial action and emergency powers of the HFSA (structural benchmark). In December 2008, we granted the HFSA powers to impose extraordinary reporting requirements on banks in case the stability of the financial system is threatened. We also submitted to Parliament a proposal for amendments to the Law on Credit Institutions and Financial Enterprises and other financial sector legislation. Once these amendments are adopted, there will be a higher threshold for the capital adequacy ratio (4.8 percent rather than 4.0 percent) that would enable the HFSA to take extraordinary measures. Moreover, the HFSA will have new powers to intervene in subsidiaries whose parent banks experience severe financial difficulties.

20. We are committed to further strengthen the remedial powers of the HFSA and the bank resolution regime. We will therefore expand the scope of the amendments mentioned in the previous paragraph in line with international sound practices. In particular, the amended legislation will (i) strengthen the provisions on the appointment and role of the supervisory commissioner (including by defining certain thresholds where appointment of the supervisory commissioner becomes mandatory); (ii) ensure adequate legal protection for the supervisory commissioner; (iii) refine and complement the powers for the use of specific bank resolution techniques, in particular in bank liquidation proceedings (including purchaseand-assumption transactions and bridge banks); and (iv) affirm that the HFSA has the sole authority for the initiation of bank liquidation proceedings. Passage by Parliament of amendments that include the above-stated elements is envisaged by end-June 2009 (structural benchmark). Moreover, we will carefully study the feasibility of establishing a more comprehensive range of resolution tools to be applied once a supervisory commissioner has been appointed by the HFSA, including an effective mechanism for limiting shareholders' governance rights to facilitate efficient and least-cost bank resolution.

21. Together with these improvements in the legal framework, we will strengthen the operational capabilities of the HFSA in the field of on-site bank examinations. To this end, we will develop an action plan by end-May 2009 (structural benchmark), including training programs for HFSA staff and possible technical assistance from other institutions. As an immediate step, the HFSA has included in its 2009 supervisory plan expanded examinations of the key banks, including in particular an assessment of the impact of the worsening economic outlook on the banking sector. We will also explore ways to move towards a more 
forward-looking and risk-based supervisory approach, in line with international best practice and fundamental Hungarian legal principles. In addition, we will continue strengthening collaboration and exchange of information with foreign supervisory authorities, including by means of Memoranda of Understanding with authorities in the region.

22. We are also continuing initiatives to facilitate an orderly private debt resolution process while preserving credit discipline. The new initiatives include: (i) extending the agreement with the banks (originally reached in November 2008) for voluntary household debt restructuring until end-2009; and (ii) introducing legislation to provide temporary government guarantees for mortgage payments on primary residences by persons that have become unemployed, with incentives and safeguards to facilitate orderly restructuring, support credit discipline, and minimize potential costs for the government. In addition, we will strengthen the corporate bankruptcy framework by establishing mechanisms for firm restructuring and rehabilitation, in addition to the existing liquidation procedures.

\section{Monetary and Exchange Rate Policy}

23. The MNB remains committed to the inflation target of 3 percent over the medium term, while being prepared to act as needed to mitigate risks to financial stability. Reflecting the rapid deceleration in inflation pressures in recent months, the MNB's key policy rate has been cut by 200 bps since November 2008. Going forward, the MNB projects that inflation will remain within the $3 \pm 1$ percent band specified by our inflation targeting framework. The quarterly targets for CPI inflation under the program are consistent with this framework, which will be monitored under the inflation consultation mechanism.

24. A key objective of the government's economic program remains to gradually build up an adequate level of international reserves. The target for NIR under the program is designed to meet this objective, while allowing room for stabilizing market conditions in a fragile external environment. The government will refrain from issuing short-term debt for the purpose of meeting the NIR target.

25. Since October 2008, the MNB has established a range of new facilities to inject foreign currency and forint liquidity. The facilities include a forint term lending facility and two overnight foreign exchange swap facilities, backed by a repo facility with the European Central Bank. Moreover, the MNB has widened the eligible collateral for transactions with the central bank by including mortgage bonds of associated banks and municipal bonds. The new liquidity facilities were used heavily during the turbulence in October and November. While interest in these facilities has fallen recently given improved liquidity, the MNB intends to keep them in place to insure against future turbulence. In addition, on February 2, it introduced a one-week Swiss franc liquidity providing fixed price euro/Swiss franc swap tender, backed by a swap agreement with the Swiss National Bank. To facilitate term foreign exchange funding, the MNB introduced on March 2, 2009, euro-liquidity providing 6-month euro/forint swap tenders, whose use is subject to certain conditions. These include a 
requirement to roll-over funding from non-residents with original maturity of more than one year and/or to reduce foreign assets, as well as maintaining the level of lending to Hungary's corporate sector in nominal terms. A supplementary 3-months FX swap facility with unconditional access was also introduced, with a spread of at least 50 bps over the 6-month facility. More generally, the MNB stands ready to extend its toolkit as needed to safeguard financial stability.

János Veres /s /

Minister of Finance
András Simor /s /

Governor of the MNB

Attachments 
Table 1. Hungary: Program Monitoring

Measure

\section{Quantitative Performance Criteria}

1 Floor on the cash primary balance of the central government system

2 Floor on net international reserves

\section{Continuous Performance Criteria}

Non-accumulation of external debt arrears

Inflation Consultation Clause

Inner band

Outer band

Indicative Target

Ceiling on total debt stock of the central government system

\section{Structural Performance Criterion}

Submission to parliament of draft support package for domestic banks and request initiation of extraordinary

procedure for early passage (by November 10, 2008)

\section{Structural Benchmarks}

1 Passage of the draft fiscal responsibility law (by end-December, 2008)

2 Submission to parliament of a law granting the HFSA special remedial powers to accelerate the resolution of any failed bank (by end-December 2008)
December 2008

Observed

Observed

Observed

Lower limit breached-discussion with staff held.

Observed

Observed

Observed

Observed

Observed 
Table 2. Hungary: Quantitative Program Targets

\begin{tabular}{|c|c|c|c|c|c|c|c|}
\hline & \multicolumn{3}{|c|}{2008} & \multicolumn{4}{|c|}{2009} \\
\hline & \multirow{3}{*}{$\begin{array}{r}\text { end-Sep } \\
\text { Actual }\end{array}$} & & & \multirow{3}{*}{$\begin{array}{r}\text { End-Mar } \\
\text { Prog. }\end{array}$} & \multirow{3}{*}{$\begin{array}{r}\text { End-Jun } \\
\text { Prog. }\end{array}$} & \multicolumn{2}{|c|}{ Program projections } \\
\hline & & \multicolumn{2}{|c|}{ end-Dec } & & & End-Sep & End-Dec \\
\hline & & Prog. & Outcome & & & & \\
\hline \multicolumn{8}{|l|}{ I. Quantitative Performance Criteria } \\
\hline $\begin{array}{l}\text { 1. Overall floor on the cumulative cash primary balance of the central government } \\
\text { system (floor, in billions of forints) } 1 /\end{array}$ & 130.3 & 215 & 226 & -280 & -55 & 155 & 440 \\
\hline 2. Cumulative change in net international reserves (floor, in millions of euros) $2 / 3 /$ & 17,096 & $\ldots$ & +1397.8 & $\ldots$ & $\ldots$ & $\ldots$ & $\ldots$ \\
\hline \multicolumn{8}{|l|}{ II. Continuous Performance Criterion } \\
\hline 3. Non-accumulation of external debt arrears & $\ldots$ & 0 & 0 & 0 & 0 & 0 & 0 \\
\hline \multicolumn{8}{|l|}{ III. Inflation Consultation } \\
\hline \multicolumn{8}{|l|}{ 4. 12-month rate of inflation in consumer prices $4 /$} \\
\hline Outer band (upper limit) & $\ldots$ & 7.1 & & 5.0 & 5.0 & 5.0 & 5.0 \\
\hline Inner band (upper limit) & $\ldots$ & 6.1 & & 4.0 & 4.0 & 4.0 & 4.0 \\
\hline Central point & 5.7 & 5.1 & 3.5 & 3.0 & 3.0 & 3.0 & 3.0 \\
\hline Inner band (lower limit) & $\ldots$ & 4.1 & & 2.0 & 2.0 & 2.0 & 2.0 \\
\hline Outer band (lower limit) & $\ldots$ & 3.1 & & 1.0 & 1.0 & 1.0 & 1.0 \\
\hline \multicolumn{8}{|l|}{ III. Indicative Target } \\
\hline $\begin{array}{l}\text { 5. Ceiling on the total debt stock of the central government system } \\
\text { (in billions of forints) } 5 /\end{array}$ & 15,973 & 16,320 & 15,925 & 15,872 & 15,645 & 15,526 & 15,487 \\
\hline
\end{tabular}

$1 /$ Cumulative flows from the beginning of the calendar year.

2/ The end-September 2008 NIR figure is a stock. The change in NIR for December is from September 2008, the cumulative changes for 2009 are from December 2008 B10(18494). 3/ NIR stock is adjusted upward (downward) for any increase (decrease) in the actual disbursement compared to program disbursements, and for any shortfall (surplus) of the Bank

Guarantee Fund relative to the baseline projection up to a ceiling of $€ 5$ billion (see TMU).

4/ The inner band for consultation is $+/-1$ percentage points around the central point, and the outer band is $+/-2$ percentage points around the central point.

$5 /$ Foreign-currency denominated debt calculated at program exchange rates. 
Table 3. Structural Conditionality through end-June 2009

\section{Measure}

\section{Structural Performance Criteria}

1. Submission to Parliament of all legislative changes required to implement the measures on pension reform described in paragraph 15, first bullet point

end-March 2009

2. Submission to Parliament of amendments to the Financial Stability Act as listed in Paragraph 18

end-March 2009

3. Establishment of a sub-committee of the tripartite

Financial Stability Committee to monitor the financial soundness and stress-resilience of banks that receive capital or refinancing support from the government, as described in Paragraph 18

end-March 2009

\section{Structural Benchmarks}

1. Passage by parliament of the amendments strengthening the remedial powers of the HFSA and bank resolution regime as listed in paragraph 20

end-June 2009

2. Development of an action plan to strengthen the operational capabilities of the HFSA in the field of on-site bank examinations

end-May 2009

3. Operation of the new sub-committee described in Paragraph 18 as long as there is any government capital or funding support outstanding to banks, and consultation of the sub-committee with Fund staff on its work program. 


\section{AtTachment II. Hungary: TeChniCAl Memorandum of Understanding (TMU)}

March 11, 2009

1. This Technical Memorandum of Understanding (TMU) defines the variables subject to quantitative targets (performance criteria and indicative targets), specified in the Letter of Intent (LOI). It also describes the methods to be used in assessing the program performance and the information requirements to ensure adequate monitoring of the targets. Reference to "days" in this TMU should be understood to mean "business days in Budapest".

2. The exchange rates for the purposes of the program of the Hungarian forint (HUF) to the euro is set at HUF $243.17=€ 1$, to the U.S. dollar at HUF $169.15=\$ 1$, and to the Swiss franc at HUF 154.01 = CHF 1, the rates as shown on the Hungarian central bank's (Magyar Nemzeti Bank, MNB) website as of September 30, $2008 .{ }^{1}$

\section{Central Government System}

3. Definition: The central government system (CGS) is defined to include the central government (state budget), extrabudgetary funds, and social security funds. In case the government establishes new extrabudgetary funds, they will be consolidated within the central government system.

\section{Quantitative Performance Criteria, Indicative Ceiling, and Continuous Performance Criteria: Definitions and Reporting Standards}

\section{A. Floor on the Net International Reserves of the MNB}

\begin{tabular}{ll}
\hline & $\begin{array}{c}\text { (In millions } \\
\text { of euros) }\end{array}$ \\
\hline Outstanding stock: & \\
$\quad$ End-December 2008 & $18,493.8$ \\
Floor on cumulative change in net international reserves & \\
from end-December 2008: & \\
End- March 2009 (performance criterion) & $\ldots$ \\
End-June 2009 (performance criterion) & $\ldots$ \\
End-September 2009 (indicative target) & $\ldots$ \\
End-December 2009 (indicative target) & $\ldots$ \\
\hline
\end{tabular}

4. Net international reserves (NIR) of the central bank of Hungary (MNB) are defined as the euro value of gross foreign assets of the MNB minus gross foreign liabilities of the

\footnotetext{
${ }^{1}$ These exchange rates were derived from the file posted on the MNB website at http://english.mnb.hu/Resource.aspx?ResourceID $=$ mnbarfolyamfile $\& \mathrm{f}=0$.
} 
MNB with maturity of less than one year and all of the government's credit outstanding from the Fund. Non-euro denominated foreign assets and liabilities will be converted into euro at the program exchange rates. Data will be provided by the MNB to the Fund with a lag of not more than five days past the test date.

5. Gross foreign assets are defined consistently with SDDS as readily available claims on nonresidents denominated in foreign convertible currencies. They include the MNB's holdings of monetary gold, SDRs, foreign currency cash, foreign currency securities, deposits abroad, and the country's reserve position at the Fund. Excluded from reserve assets are any assets that are pledged, collateralized, or otherwise encumbered, claims on residents, claims in foreign exchange arising from derivatives in foreign currencies vis-à-vis domestic currency (such as futures, forwards, swaps, and options), precious metals other than gold, assets in nonconvertible currencies, and illiquid assets.

6. Gross foreign liabilities are defined consistently with SDDS as all foreign exchange liabilities to residents and nonresidents, including commitments to sell foreign exchange arising from derivatives (such as futures, forwards, swaps, and options), and banks foreign currency deposits against reserve requirements. Government foreign exchange deposits and forward liabilities arising from swap arrangements with the MNB are not treated as foreign liability of the MNB.

7. NIR targets will be adjusted upward (downward) by the surplus (shortfall) in program disbursements relative to the baseline projection. Program disbursements are defined as external disbursements from official creditors that are usable for the financing of the overall central government budget. NIR target will be adjusted upward (downward) by the shortfall (surplus) of the Bank Guarantee Fund relative to the baseline projection, up to a ceiling of $€ 5$ billion.

\section{External Program Disbursements (Baseline Projection)}

\begin{tabular}{lc}
\hline Cumulative flows from end-December 2008: & $\begin{array}{c}\text { (In millions } \\
\text { of euros) }\end{array}$ \\
\hline End-March 2009 (program projection) & 2,000 \\
End-June 2009 (program projection) & 4,000 \\
End-September 2009 (program projection) & 4,000 \\
End-December 2009 (program projection) & 5,500 \\
\hline
\end{tabular}

Resources Used for the Bank Guarantee Fund (Baseline Projection)

\begin{tabular}{lc} 
Cumulative flows from end-December 2008: & $\begin{array}{c}\text { (In millions } \\
\text { of euros) }\end{array}$ \\
\hline End-March 2009 (program projection) & 0 \\
End-June 2009 (program projection) & 2,069 \\
End-September 2009 (program projection) & 2,069 \\
End-December 2009 (program projection) & 2,069 \\
\hline
\end{tabular}




\section{B. Consultation Mechanism on the 12-month Rate of Inflation}

8. The quarterly consultation band for the 12-month rate of inflation in consumer prices is based on the measure of the headline consumer price index (CPI) published by the Hungarian Central Statistical Office). Consistent with the headline CPI inflation target of the MNB, the central point for end-quarter inflation will be 3 percent, with lower and upper bands around each target of \pm 1 and \pm 2 , respectively. Given the faster-than-expected decline in CPI inflation in recent months, the target for end-March 2009 will be modified to the above target. The targets for end-March 2009 and end-June 2009 are performance criteria, while those for end-September 2009 and end-December 2010 are indicative targets.

\section{The CPI inflation consultation band will be an important part of each review}

under the arrangement. In line with our accountability principles, we are committed to report to the public the reasons for any breach of the inner band and our policy response. In this vein, the MNB will conduct discussions with the Fund staff should the observed year-onyear rate of CPI inflation fall outside the inner band. In addition, should the observed yearon-year rate of CPI inflation fall outside the outer band specified above, the authorities will complete a consultation with the Fund on their proposed policy response before requesting further purchases under the program.

\section{Floor on the Cash Primary Balance of the Central Government System}

\begin{tabular}{lc}
\hline & (In billions of forints) \\
\hline Cumulative primary balance from January 1, 2009: & -280 \\
End-March 2009 (performance criterion) & -55 \\
End-June 2009 (performance criterion) & 155 \\
End-September 2009 (indicative target) & 440 \\
End-December 2009 (indicative target) & \\
\hline
\end{tabular}

10. The primary balance of a budgetary institution is defined as the difference between total revenues and non-interest expenditures of that institution.

11. The floor on the primary balance of the CGS will be monitored from above the line on a cash basis. It is understood that transfers among entities of the CGS are mutually consistent; hence, the difference between the simple sum of revenues and the simple sum of primary expenditures across all CGS entities yields the consolidated CGS balance. Should discrepancies arise, reconciliation between reported transfers and reported revenues from other CGS entities will be required before compliance with the CGS primary balance ceiling can be assessed. Data will be provided by the Ministry of Finance to the IMF with a lag of no more than seven days past the test date. 
12. For the purpose of the program, the primary expenditure of the CGS excludes any cash payment related to bank recapitalization (to establish the Capital Enhancement Fund) and to transfers to the Bank Guarantee Fund.

13. Net lending of any component of the CGS will be considered as a non-interest expenditure item, whereas negative net lending of any component of the CGS will be considered as a revenue item.

\section{Indicative Ceiling on Overall Stock of Debt of the Central Government System}

14. The ceiling on the overall stock of the debt, as outlined below, shall apply to the HUF value of total stock of debt contracted by the central government system. Excluded from this indicative ceiling are credits from the IMF, external program financing, normal trade-related credits, reserve and long-term liabilities of the MNB, and the absolute net value of mark-tomarket deposits of the Hungarian Debt Management Agency (ÁKK). ${ }^{2}$ Liabilities related to the bank support package are not included. All stated benchmarks of ÁKK in terms of public debt management will be maintained as much as possible, depending on market conditions and the possible use of IMF credit.

\begin{tabular}{lc}
\hline Outstanding stock: & (In billions of forints) \\
\hline End-December 2008 (actual) & 15,925 \\
End-March 2009 (indicative ceiling) & 15,872 \\
End-June 2009 (indicative ceiling) & 15,645 \\
End-September 2009 (indicative ceiling) & 15,526 \\
End-December 2009 (indicative ceiling) & 15,487 \\
\hline
\end{tabular}

15. Data on the total stock of debt of the central government system will be provided to the IMF by ÁKK on a quarterly basis within 10 days of the end of each quarter.

16. The program exchange rate will apply to all non-HUF denominated debt.

17. The indicative ceiling will also be adjusted upward (downward) by the shortfall (surplus) in net EU transfers relative to the baseline projection which forms the basis of the government budget and financing plans. The term "net EU transfers" refers to the net effect

\footnotetext{
${ }^{2}$ According to ÁKK's benchmarks, foreign currency debt should be kept wholly in euro denomination and the interest rate composition is also fixed. To meet this benchmark while issuing debt in non-euro currency - such as the U.S. dollar, Japanese Yen, and the Pound Sterling-ÁKK uses cross-currency and interest rate swaps. To limit counterparty risks in such transactions, ÁKK places (or accepts) cash deposits as collaterals. Any such deposit thus increases public debt for reasons autonomous to the government's financing plans. For this reason, these mark-to-market operations are excluded from the indicative ceiling.
} 
of pre- and post-financing of certain EU transfers, which are excluded from the public deficit but included in the public debt.

\section{Net EU Transfers (Baseline Projection)}

\begin{tabular}{lc}
\hline & (In billions of forints) \\
\hline Easeline projections: & 207.65 \\
End-June 2009 (program projection) & 12.62 \\
End-September 2009 (program projection) & -103.40 \\
End-December 2009 (program projection) & -167.59 \\
\hline
\end{tabular}

18. The indicative ceiling will also be adjusted upward (downward) for an increase (decrease) of the ÁKK's cash reserves (built for liquidity management purposes) in the Single Treasury Account held at the MNB relative to the baseline projection.

\section{Cash reserves at the Single Treasury Account (Baseline Projection)}

\begin{tabular}{lc}
\hline Baseline projections: & (In billions of forints) \\
\hline End-March 2009 (program projection) & 295.93 \\
End-June 2009 (program projection) & 452.11 \\
End-September 2009 (program projection) & 120.53 \\
End-December 2009 (program projection) & 118.97 \\
\hline
\end{tabular}

\section{E. Continuous Performance Criteria on Non-accumulation of External Debt Payments Arrears by the Central Government System}

19. The central government system will accumulate no new external debt arrears during the program period. For the purposes of this performance criterion, an external debt payment arrear will be defined as a payment by the central government system, which has not been made within seven days after falling due.

20. The stock of external arrears of the central government system will be calculated based on the schedule of external payments obligations reported by the ÁKK. Data on external arrears will be reconciled with the relevant creditors, and any necessary adjustments will be incorporated in these targets as they occur.

21. The performance criterion will apply on a continuous basis. The ÁKK will provide the final data on the stock of the central government system external arrears to the Fund, with a lag of not more than seven days after the test date. This performance criterion does not cover trade credits. 


\section{INTERNATIONAL MONETARY FUND}

\section{HUNGARY}

First Review Under the Stand-By-Arrangement and Request for Modification of Performance Criteria-Informational Annex

\section{Prepared by the European Department}

March 12, 2009

Contents

Page

Appendix

I. Fund Relations ...... 


\section{APPENDIX I HUNGARY: FUND RELATIONS}

(As of February 28, 2009)

I. Membership Status: Joined on May 6, 1982; Article VIII.

II. General Resources Account:

$\begin{array}{cr}\text { SDR Million } & \begin{array}{r}\text { Percent } \\ \text { of Quota }\end{array} \\ 1,038.40 & 100.00 \\ 5,179.57 & 498.80 \\ 73.83 & 7.11\end{array}$

III. SDR Department

SDR Million Allocation

Holdings

10.04

N/A

IV. Outstanding Purchases and Loans:

Percent

SDR Million of Quota

Stand-By Arrangements

$4,215.00$

405.91

V. Financial Arrangements:

$\begin{array}{lcccc}\text { Type } & \begin{array}{c}\text { Approval } \\ \text { Date }\end{array} & \begin{array}{c}\text { Expiration } \\ \text { Date }\end{array} & \begin{array}{c}\text { Amount } \\ \text { Approved } \\ \text { (SDR Million) }\end{array} & \begin{array}{c}\text { Amount } \\ \text { Drawn } \\ \text { (SDR Million) }\end{array} \\ \text { Stand-by } & 11 / 6 / 08 & 4 / 5 / 10 & 10,537.50 & 4215.00 \\ \text { Stand-by } & 3 / 15 / 96 & 2 / 14 / 98 & 264.18 & 0.00 \\ \text { Stand-by } & 9 / 15 / 93 & 12 / 14 / 94 & 340.00 & 56.70\end{array}$

VI. Projected Obligations to Fund: (SDR million; based on existing use of resources and present holdings of SDRs)

\begin{tabular}{lrrrrr} 
& \multicolumn{5}{c}{ Forthcoming } \\
\cline { 2 - 6 } & 2009 & 2010 & 2011 & 2012 & 2013 \\
\hline Principal & & & $2,017.50$ & $2,017.50$ & \\
Charges/Interest & 74.46 & 99.40 & 73.67 & 22.04 & 0.25 \\
Total & 74.46 & 99.40 & 2181.17 & 2129.54 & 0.25
\end{tabular}

VII. Exchange Rate Arrangement:

The Hungarian forint is freely floating, effective February 26, 2008.

\section{Article IV Consultations:}

Hungary is on a 12-month consultation cycle. The last Article IV Board discussion took place on September 17, 2008. The associated Executive Board assessment is available at http://www.imf.org/external/np/sec/pn/2008/pn08124.htm and the staff report and other 
mission documents at http://www.imf.org/external/pubs/cat/longres.cfm?sk=22374.0 and http://www.imf.org/external/pubs/cat/longres.cfm?sk=22375.0 . Hungary has accepted the obligations of Article VIII and maintains an exchange rate system free of restrictions on the making of payments and transfers on current international transactions except for those maintained solely for the preservation of national or international security and that have been notified to the Fund pursuant to Executive Board Decision No. 144-(52/51).

IX. Technical Assistance:

\begin{tabular}{llll}
\hline Year & Department. & Purpose & Date \\
\hline 1995 & FAD & Tax administration & February \\
1995 & FAD & Treasury & February \\
1995 & FAD & Treasury & May \\
1995 & FAD & Treasury & November \\
1995 & FAD & Debt management & November \\
1995 & MAE & Central bank internal auditing & November \\
1995 & MAE & Monetary analysis and research & December \\
1996 & FAD & Tax policy & May \\
1996 & MAE & Central bank accounts & September \\
1996 & FAD & Subsidies & November \\
1997 & FAD & Subsidies follow-up & May \\
2000 & MAE & FSAP & February \\
2000 & FAD & Tax legislation & June \\
2000 & STA & Money and banking statistics & October \\
2000 & FAD & Tax legislation follow-up & November \\
2002 & FAD & Expenditure rationalization & November \\
2004 & STA & ROSC update of the fiscal sector & January \\
2005 & MFD & FSAP update & February \\
2005 & FAD & Tax policy and administration & October \\
2006 & FAD & Fiscal ROSC & May \\
2006 & FAD & Public-private partnership & September \\
2007 & FAD & Tax policy & April \\
2007 & FAD & Public financial management & June \\
2007 & FAD & Tax administration & October \\
2008 & FAD & Pension reform & May \\
2008 & FAD & Tax administration & October \\
2009 & FAD & Tax administration & March \\
\hline
\end{tabular}

\section{Resident Representative:}

Ms. Iryna Ivaschenko has been appointed Resident Representative and is expected to assume her duties shortly. 


\section{Statement by the IMF Staff Representative on Hungary \\ March 25, 2009}

1. This statement reports on key financial market and economic developments since the staff report was finalized on March 12. The new information does not alter the thrust of the staff appraisal.

2. Financial markets have remained volatile. After reaching an all-time low of 316 against the euro on March 6, the exchange rate has recovered some ground. This has reflected a combination of factors, including the Hungarian central bank's announcement that it would intervene to stem depreciation, the Swiss National Bank's announcement that it would intervene to limit the appreciation of the Swiss franc, and a general improvement in global investor sentiment. In line with the recovery of the exchange rate, Hungary's government bond and CDS spreads have narrowed, although they remain at elevated levels. At its meeting on March 23, the monetary council of the central bank left the policy rate unchanged at 9.5 percent, while emphasizing downside risks to financial stability.

\section{Recent macroeconomic data underscore the severity of the economic downturn} and the downside risks to the outlook. GDP data for 2008Q4 indicate a contraction in real terms of 2.3 percent year-on-year, slightly larger than in the flash estimate. The decline was broad-based, with negative contributions from private consumption, public consumption, and gross fixed capital formation. The decomposition of the January industrial output data shows that the 23 percent fall (year-on-year) was mostly due to export markets, especially a plunge in automobile demand in the euro area. Wage growth declined in January, reflecting not only smaller public sector bonus payments but also lower private sector wage growth excluding bonuses. 


\section{IMF Completes First Review Under Stand-By Arrangement with Hungary and Approves €2.35 Billion Disbursement}

The Executive Board of the International Monetary Fund (IMF) today completed the first review of Hungary's economic performance under a program supported by a 17-month Stand-By Arrangement (SBA). The completion of the review enables the immediate disbursement of an amount equivalent to SDR 2.11 billion (about $€ 2.35$ billion or US\$3.19 billion), bringing total disbursements under the program to an amount equivalent to SDR 6.32 billion (about $€ 7.05$ billion or US $\$ 9.56$ billion).

The SBA was approved on November 6, 2008 (see Press Release No. 08/275) for an amount equivalent to SDR 10.5 billion (about $€ 11.76$ billion or US $\$ 15.94$ billion). The arrangement entails exceptional access to IMF resources, amounting to 1,015 percent of Hungary's quota.

Following the Executive Board's discussion on Hungary, Mr. John Lipsky, First Deputy Managing Director and Acting Chair, stated:

"Against the backdrop of a worsening economic outlook and the persistence of financial market stress, policy implementation has been steadfast and responsive. All quantitative performance criteria and indicative target and the structural performance criterion and benchmarks for the fourth quarter of 2008 were met. However, economic growth in partner countries and global financial market conditions are turning out to be worse than anticipated when the program was agreed in November 2008. To address these challenges, the policy settings under the program have been adapted to strike the right balance between preserving creditor confidence in the soundness of Hungary's fiscal and balance of payments positions and avoiding measures that would further deepen the recession.

"The additional fiscal measures aim to strengthen fiscal sustainability while avoiding an excessively large negative impulse to demand, by combining permanent reductions in spending with a small rise in the 2009 budget deficit relative to the original program. The revised program puts additional emphasis on measures to safeguard essential social spending 
and help preserve financial stability, including ensuring the continuity of the safety net for banks, strengthening the remedial action and resolution regimes, and improving the capabilities of the Hungarian Financial Supervision Agency. Monetary policy will continue to target inflation over the medium term, while being prepared to act quickly as needed to mitigate risks to financial stability.

"In the context of the ongoing turmoil in global financial markets, strong implementation of the program will bolster Hungary's economic prospects, supported by large external financial support that provides reassurance that Hungary's external obligations can be met. The joint financial assistance being provided by the IMF, the European Union, the World Bank, and other multilateral partners sends a strong signal of the international community's confidence that, with the consistent implementation of the program, Hungary will weather the current difficulties," Mr. Lipsky stated. 